\title{
Quantum Surprises from the Watson-Crick and Hoogsteen G.C Nucleobase Pairs: A Comprehensive QM/QTAIM Investigation
}

Ol'ha 0. Brovarets ( $D$ o.o.brovarets@gmail.com )

Institute of Molecular Biology and Genetics National Academy of Sciences of Ukraine https://orcid.org/0000-0002-8929-293X

Alona Muradova

Taras Shevchenko National University of Kyiv

Dmytro M. Hovorun

Institute of Molecular Biology and Genetics National Academy of Sciences of Ukraine

\section{Research Article}

Keywords: DNA, RNA, G.C nucleobase pair, tautomerization, transition state, mutagenic tautomer, tight ion pair, quantum-chemical calculations, mutations

Posted Date: December 3rd, 2021

DOI: https://doi.org/10.21203/rs.3.rs-1109763/v1

License: (1) (i) This work is licensed under a Creative Commons Attribution 4.0 International License. Read Full License 


\title{
Quantum surprises from the Watson-Crick and Hoogsteen G·C nucleobase pairs: A comprehensive QM/QTAIM investigation
}

\author{
Ol'ha O. Brovarets ${ }^{\bowtie}$, Alona Muradova ${ }^{2} \&$ Dmytro M. Hovorun ${ }^{1,2}$ \\ ${ }^{1}$ Department of Molecular and Quantum Biophysics, Institute of Molecular Biology and Genetics, National Academy of \\ Sciences of Ukraine, 150 Akademika Zabolotnoho Street, 03680, Kyiv, Ukraine \\ ${ }^{2}$ Department of Molecular Biotechnology and Bioinformatics, Institute of High Technologies, Taras Shevchenko National \\ University of Kyiv, 2-h Akademika Hlushkova Avenue, 03022, Kyiv, Ukraine \\ ${ }^{凶}$ Corresponding author. E-mail: o.o.brovarets@gmail.com
}

\begin{abstract}
In this study at the MP2/6-311++G(d,p)//B3LYP/6-311++G(d,p) level of theory in the isolated state it was revealed 14 novel physico-chemical mechanisms of the tautomerization of the $\mathrm{G} \cdot \mathrm{C}$ nucleotide base pairs in the Watson-Crick $\mathrm{G} \cdot \mathrm{C}(\mathrm{WC}) / \mathrm{G}^{*} \cdot \mathrm{C}^{*}(\mathrm{WC})$, reverse Watson-Crick $\mathrm{G}^{*} \cdot \mathrm{C}^{*}(\mathrm{rWC}) / \mathrm{G} \cdot \mathrm{C}^{*} \mathrm{O} 2(\mathrm{rWC}), \quad$ Hoogsteen $\mathrm{G}^{* \mathrm{t}} \cdot \mathrm{C}^{*}(\mathrm{H}) / \mathrm{G}^{*}{ }_{\mathrm{N} 7} \cdot \mathrm{C}(\mathrm{H})$ or reverse Hoogsteen $\mathrm{G}^{* \mathrm{t}} \cdot \mathrm{C}^{*}(\mathrm{rH}) / \mathrm{G}^{* \mathrm{t}} \mathrm{N} \cdot \mathrm{C}(\mathrm{rH})$ configurations into the wobble $\left(\mathrm{w}_{\mathrm{WC}}, \mathrm{w}_{\mathrm{H}}\right)$ and reverse wobble $\left(\mathrm{rw}_{\mathrm{WC}}, \mathrm{rw}_{\mathrm{H}}\right)$ base pairs: $\quad 1 . \mathrm{G} \cdot \mathrm{C}(\mathrm{WC}) \leftrightarrow \mathrm{G} \cdot \mathrm{C}^{*}\left(\mathrm{rw}_{\mathrm{WC}}\right), \quad 2 . / 3 \cdot \mathrm{G}^{*} \cdot \mathrm{C}^{*}(\mathrm{WC}) \leftrightarrow \mathrm{G} \cdot \mathrm{C}^{*}\left(\mathrm{rw}_{\mathrm{WC}}\right) / \mathrm{G}^{*}{ }_{\mathrm{N} 2} \cdot \mathrm{C}^{*}\left(\mathrm{rwWC}_{\mathrm{WC}}\right)$, 4. $\mathrm{G}^{*} \cdot \mathrm{C}^{*}(\mathrm{rWC}) \leftrightarrow \mathrm{G}^{*} \cdot \mathrm{C}\left(\mathrm{w}_{\mathrm{WC}}\right), \quad$ 5. G. $\mathrm{C}^{*} \mathrm{O} 2(\mathrm{rWC}) \leftrightarrow \mathrm{G} \cdot \mathrm{C}^{*}\left(\mathrm{w}_{\mathrm{WC}}\right)$; 6./7./8./9. $\mathrm{G}^{*^{\mathrm{t}}} \cdot \mathrm{C}^{*}(\mathrm{H}) \leftrightarrow \mathrm{G}^{* \mathrm{t}} \cdot \mathrm{C}\left(\mathrm{rw}_{\mathrm{H}}\right) / \mathrm{G}^{* \mathrm{t}} \cdot \mathrm{C}^{*}{ }_{\mathrm{O} 2}\left(\mathrm{w}_{\mathrm{H}}\right) / \mathrm{G}^{* \mathrm{t}} \cdot \mathrm{C}^{*} \mathrm{O} 2_{2}\left(\mathrm{rw}_{\mathrm{H}}\right) / \mathrm{G}^{* \mathrm{t}}{ }_{\mathrm{N} 7} \cdot \mathrm{C}^{*}\left(\mathrm{rw}_{\mathrm{H}}\right) \leftrightarrow \mathrm{G}^{* \mathrm{t}} \cdot \mathrm{C}^{*} \mathrm{O} 2_{2}\left(\mathrm{rw}_{\mathrm{H}}\right)$, 10. $\mathrm{G}^{*}{ }_{\mathrm{N} 7} \cdot \mathrm{C}(\mathrm{H}) \leftrightarrow \mathrm{G}^{* \mathrm{t}} \cdot \mathrm{C}\left(\mathrm{w}_{\mathrm{H}}\right)_{\mathrm{amino}}$, 11./12. $\mathrm{G}^{* \mathrm{t}} \cdot \mathrm{C}^{*}(\mathrm{rH}) \leftrightarrow \mathrm{G}^{*}{ }_{\mathrm{N} 7} \cdot \mathrm{C}^{*}\left(\mathrm{w}_{\mathrm{H}}\right) / \mathrm{G}^{* \mathrm{t}} \cdot \mathrm{C}\left(\mathrm{w}_{\mathrm{H}}\right)$, 13. $\mathrm{G}^{* \mathrm{t}}{ }_{\mathrm{N} 7} \cdot \mathrm{C}(\mathrm{rH}) \leftrightarrow \mathrm{G}^{* \mathrm{t}}{ }_{\mathrm{N} 7} \cdot \mathrm{C}^{*}\left(\mathrm{w}_{\mathrm{H}}\right) \leftrightarrow \mathrm{G}^{* \mathrm{t}} \cdot \mathrm{C}\left(\mathrm{w}_{\mathrm{H}}\right) \quad$ and $\quad 14 . \mathrm{G}^{*}{ }_{\mathrm{N} 7} \cdot \mathrm{C}^{*}\left(\mathrm{rw}_{\mathrm{H}}\right) \leftrightarrow \mathrm{G}^{*}{ }_{\mathrm{N} 7} \cdot \mathrm{C}^{*}\left(\mathrm{rw}_{\mathrm{H}}\right)_{\text {perp }} \leftrightarrow \mathrm{G}^{-}$ $\cdot \mathrm{C}^{+}\left(\mathrm{w}_{\mathrm{H}}\right) \leftrightarrow \mathrm{G}^{*^{\mathrm{t}}}$. $\mathrm{C}\left(\mathrm{rw}_{\mathrm{H}}\right)$ reaction pathways. It was established that the presence in the base pair of the two anti-parallel neighboring H-bonds is a necessary and sufficient condition for the implementation of such transformations, since it enables intermolecular proton transfer between the bases inside the base pair. It was found out that these tautomeric transitions are controlled by the TSs with quasiorthogonal structure, which are tight $\mathrm{G}^{+} \cdot \mathrm{C}^{-} / \mathrm{G}^{-} \cdot \mathrm{C}^{+}$ion pairs, joined by at least two parallel intermolecular H-bonds, connected on a common negatively charged endocyclic $\mathrm{N}^{-} / \mathrm{C}^{-}$atoms proton acceptor. All reaction pathways have been reliably confirmed. These transitions are accompanied by the changing of the mutual cis-orientation of the $\mathrm{N} 9 \mathrm{H}$ and $\mathrm{N} 1 \mathrm{H}$ glycosidic bonds of the bases on the trans-orientation and vice versa. These data complement the reported earlier mechanisms of the tautomerisations of the classical A.T and G.C DNA base pairs. Experimental verification of the novel G.C nucleobase pairs is looking as an attractive task for the future research.
\end{abstract}

Key words: DNA; RNA; G.C nucleobase pair; tautomerization; transition state; mutagenic tautomer; tight ion pair; quantum-chemical calculations. 


\section{INTRODUCTION.}

The topic of tautomerism is of paramount importance nowadays [1-7], since, from the one side, it enables to explain the chemical structure of the biomolecules, and, from the other side their functioning in the living cell.

In general, this topic attracted active researchers' attention in different areas of research drug design, physics of crystals, in NMR spectroscopy and biologically important molecules [813]. The point of view, that in biological molecules tautomeric transformations are inseparable from the conformational transformations, is becoming more and more popular last time [3, 14]. This enables to open new possibilities for the understanding of the subtle intimate mechanisms of the functioning of the biomolecules in a living cell.

Tautomerism represents especial interest in nucleic acids [15], since transfer of single proton inside the nucleobase pairs leads to the groundbreaking changes in their structure and functioning [4]. Also, tautomerism is usually associated with the mutagenic properties of the molecules [3, 16]. Thus, recently it was found [3, 18] that sequential single proton transfer inside classical Watson-Crick A.T/G.C and unusual DNA base pairs leads to the Watson-Crick $\leftrightarrow$ wobble transitions and further formation of the wobble base pairs involving rare tautomers, which cause spontaneous point mutations.

In view of all presented in the literature data $[2,7,18,19]$ on the possible mechanisms of tautomerization, it arises quite logical question - "How complete they are?". Just answer on this biologically important question enables to establish which of them are responsible for the spontaneous point mutations and which - for the other biological roles.

This study is a further development of the previous works [20-22], devoted to the tautomerically-conformational transformations of the classical G.C DNA base pairs, leading to the formation of the mutagenic tautomers of the G and C DNA bases.

So, aim of this study - to reveal physico-chemical mechanisms, which define the tautomerization of the G.C nucleobase pair in its four biologically important configurations. These investigations have been performed at the MP2/6-311++G(2df,pd)//B3LYP/6-311++G(d,p) level of QM theory. Obtained data significantly extend existing ideas about the possible biological role of the prototropic tautomerism of the pairs of nucleotide bases in the processes of the functioning of the nucleic acids.

\section{COMPUTATIONAL METHODS.}

Density functional theory calculations of the geometry and vibrational frequencies. Equilibrium geometries of the investigated G.C nucleobase pairs and transition states (TSs) of their mutual conformationally-tautomeric transformations, as well as their harmonic vibrational frequencies have been calculated at the B3LYP/6-311++G(d,p) level of theory [23-27], using 
Gaussian'09 program package [28]. Applied level of theory has proved itself successful for the calculations of the similar systems [29, 30]. A scaling factor that is equal to 0.9668 has been applied in the present work for the correction of the harmonic frequencies of all complexes and TSs of their tautomeric and conformational transitions [31, 32]. We have confirmed the local minima and TSs, localized by Synchronous Transit-guided Quasi-Newton method [33], on the potential energy surface by the absence or presence, respectively, of the imaginary frequency in their vibrational spectra. Further, reaction pathways of the conformationally-tautomeric transformations have been confirmed by using the Intrinsic Reaction Coordinate (IRC) procedure $[20,21]$, moving from each TS in the reverse and forward directions.

All calculations have been carried out in the continuum with $\varepsilon=1$ under normal conditions $(\mathrm{T}=298.15 \mathrm{~K})[34,35]$, that adequately reflects the processes occurring in real biological systems without reduction of the intrinsically inherent structurally-functional properties of the base pairs in the composition of DNA. Moreover, this environment $(\varepsilon=1)$ satisfactorily models base pair recognition pocket of the DNA-polymerase machinery, which is substantially hydrophobic.

Single point energy calculations. Geometry optimizations have been followed by the electronic energy calculations as the single point calculations for the optimized geometries of the G.C nucleobase pairs and TSs of their conformationally-tautomeric transformations at the MP2/6$311++\mathrm{G}(2 \mathrm{df}, \mathrm{pd})$ level of theory [36, 37].

QTAIM analysis. Bader's Quantum Theory of Atoms in Molecules (QTAIM) [38-43] has been applied by using program package AIMAll [44] in order to analyze the electron density distribution. The presence of the bond critical point (BCP), namely the so-called $(3,-1) \mathrm{BCP}$, and a bond path between hydrogen donor and acceptor, as well as the positive value of the Laplacian at this BCP $(\Delta \rho>0)$, have been considered as criteria for the H-bond formation [38-43]. Wave functions have been obtained at the B3LYP/6-311++G(d,p) level of theory.

\section{OBTAINED RESULTS AND THEIR DISCUSSION.}

Obtained results are presented in Table 1 and on Figure 1. Their careful analysis revealed the data, which are analyzed in more details below.

First, it would be considered novel pathways of the tautomerizations for the G.C nucleobase pairs, which have Watson-Crick geometry with cis-oriented $\mathrm{N} 9 \mathrm{H}$ and $\mathrm{N} 1 \mathrm{H}$ glycosidic bonds and reverse Watson-Crick geometry with trans-oriented $\mathrm{N} 9 \mathrm{H}$ and $\mathrm{N} 1 \mathrm{H}$ glycosidic bonds.

1. It was established that classical Watson-Crick G.C(WC) pair of the nucleotide bases tautomerizes into the reverse wobble Watson-Crick $\mathrm{G} \cdot \mathrm{C}^{*}\left(\mathrm{rw}_{\mathrm{WC}}\right)$ nucleobase pair with transoriented $\mathrm{N} 9 \mathrm{H}$ and $\mathrm{N} 1 \mathrm{H}$ glycosidic bonds through two different pathways as from the topological, so from the energetical points of view: $1 . \mathrm{G} \cdot \mathrm{C}(\mathrm{WC}) \leftrightarrow \mathrm{G} \cdot \mathrm{C}^{*}\left(\mathrm{rw}_{\mathrm{WC}}\right)$ and

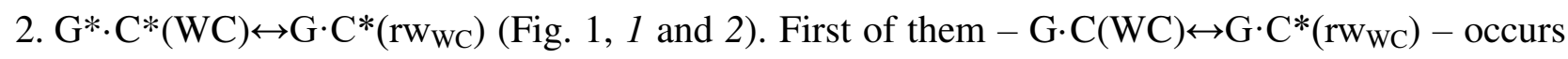


directly through the quasi-orthogonal $\mathrm{TS}^{\mathrm{G}-\cdot \mathrm{C}+}{ }_{\mathrm{G} \cdot \mathrm{C}(\mathrm{WC}) \leftrightarrow \mathrm{G} \cdot \mathrm{C}^{*}(\mathrm{rwWC})}$ transition state, which is tight ion pair - deprotonated $\mathrm{G}^{-}$-protonated $\mathrm{C}^{+}$, deprotonated by the $\mathrm{N} 1$ site of the $\mathrm{G}$ base and covered by three intermolecular specific contacts - two (C)N4 ${ }^{+} \mathrm{H} \ldots \mathrm{N1}^{-}(\mathrm{G})$ and $(\mathrm{C}) \mathrm{N} 3^{+} \mathrm{H} \ldots \mathrm{N1}{ }^{-}(\mathrm{G}) \mathrm{H}$-bonds, which are locked on the joint $\mathrm{N1}^{-}$nitrogen atom of the $\mathrm{G}^{-}$, and one attractive $(\mathrm{G}) \mathrm{O6}^{-} \ldots \mathrm{N}^{+}(\mathrm{C})$ van der Waals contact (Fig. 1, 1). Second of these mechanisms $-G^{*} \cdot C^{*}(W C) \leftrightarrow G^{*} C^{*}\left(\right.$ rw WC $\left._{\text {W }}\right)-$ occurs through the short-lived intermediate - Löwdin's $\mathrm{G}^{*} \cdot \mathrm{C}^{*}(\mathrm{WC})$ base pair and $\mathrm{TS}^{\mathrm{G}+\mathrm{C}-}$ $\mathrm{G}^{*} \cdot \mathrm{C}^{*}(\mathrm{WC}) \leftrightarrow \mathrm{G} \cdot \mathrm{C}^{*}(\mathrm{rwWC})$ transition state, tight $\mathrm{G}^{+} \cdot \mathrm{C}^{-}$ion pair, which is protonated by the $\mathrm{O} 6$ site of the $\mathrm{G}$ base and joined by two intermolecular $(\mathrm{G}) \mathrm{O6}^{+} \mathrm{H} \ldots \mathrm{N} 3^{-}(\mathrm{C})$ and $(\mathrm{G}) \mathrm{N} 1^{+} \mathrm{H} \ldots \mathrm{N} 3^{-}(\mathrm{C}) \mathrm{H}$-bonds, which are locked on the joint nitrogen $\mathrm{N}^{-}$atom of the $\mathrm{C}^{-}$(Fig. 1, 2). Obviously, that tautomeric transformation of the $\mathrm{G} \cdot \mathrm{C}(\mathrm{WC})$ base pair through the intermediate $\mathrm{G}^{*} \cdot \mathrm{C}^{*}(\mathrm{WC})$ nucleobase pair is more favorable from the energetical point of view (relative Gibbs free energy of the TS $\Delta \Delta \mathrm{G}_{\mathrm{TS}}=25.67 \mathrm{kcal} \cdot \mathrm{mol}^{-1}$ ) and thus - it is faster from the kinetical point of view (Fig. 1, 2, Table $1)$.

2. Moreover, transition of the classical G.C(WC) base pair into the Löwdin's $\mathrm{G}^{*} \cdot \mathrm{C}^{*}(\mathrm{WC})$ base pair [2] - G.C(WC)↔ $\mathrm{G}^{*} \cdot \mathrm{C}^{*}(\mathrm{WC})$ - also provides a tautomeric transition of the Löwdin's $\mathrm{G}^{*} \cdot \mathrm{C}^{*}(\mathrm{WC})$ base pair into the reverse wobble Watson-Crick $\mathrm{G}^{*}{ }_{\mathrm{N} 2} \cdot \mathrm{C}^{*}\left(\mathrm{rw}_{\mathrm{WC}}\right)$ base pair: 3. $\mathrm{G}^{*} \cdot \mathrm{C}^{*}(\mathrm{WC}) \leftrightarrow \mathrm{G}^{*}{ }_{\mathrm{N} 2} \cdot \mathrm{C}^{*}\left(\mathrm{rw}_{\mathrm{WC}}\right)$ reaction pathway (Fig. 1, 3). It is realized through the $\mathrm{TS} \mathrm{S}^{\mathrm{G}}$ ${ }^{\mathrm{C}+}{ }_{\mathrm{G}^{*} \cdot \mathrm{C}^{*}(\mathrm{WC}) \leftrightarrow \mathrm{G}^{*} \mathrm{~N} 2 \cdot \mathrm{C}^{*}(\mathrm{rwWC})}-$ tight $\mathrm{G}^{-} \cdot \mathrm{C}^{+}$ion pair, which is deprotonated by the $\mathrm{N} 1$ and $\mathrm{N} 2$ sites, protonated by the $\mathrm{O} 2$ site of the $\mathrm{G}$ base and joined by three intermolecular $(\mathrm{C}) \mathrm{O} 2^{+} \mathrm{H} \ldots \mathrm{N} 2^{-}(\mathrm{G})$, (C) $2^{+} \mathrm{H} \ldots \mathrm{N1}^{-}(\mathrm{G})$ and $(\mathrm{C}) \mathrm{N}^{+}{ }^{+} \mathrm{H} \ldots \mathrm{N1}^{-}(\mathrm{G}) \mathrm{H}$-bonds. This is the slowest tautomerization of the classical G.C(WC) base pair among all base pairs, which are considered in this work $\left(\Delta \Delta \mathrm{G}_{\mathrm{TS}}=62.00 \mathrm{kcal} \cdot \mathrm{mol}^{-1}\right)($ Table 1$)$.

3. Quite intriguing results have been obtained for the tautomerization mechanisms of the reverse Watson-Crick $\mathrm{G}^{*} \cdot \mathrm{C} *(\mathrm{rWC})$ and $\mathrm{G} \cdot \mathrm{C}^{*} \mathrm{O} 2(\mathrm{rWC})$ nucleobase pairs with trans-oriented $\mathrm{N} 9 \mathrm{H}$ and $\mathrm{N} 1 \mathrm{H}$ glycosidic bonds, the last of which is high-energetical tautomer (relative Gibbs free $\Delta \mathrm{G} /$ relative electronic $\Delta \mathrm{E}$ energy $\left.=3.41 / 3.70 \mathrm{kcal} \cdot \mathrm{mol}^{-1}\right)$ of the reverse Watson-Crick $\mathrm{G}^{*} \cdot \mathrm{C}^{*}(\mathrm{rWC})$ base pair, leading to the wobble Watson-Crick $\mathrm{G}^{*} \cdot \mathrm{C}\left(\mathrm{w}_{\mathrm{WC}}\right)$ and $\mathrm{G} \cdot \mathrm{C}^{*}\left(\mathrm{w}_{\mathrm{WC}}\right)$ nucleobase pairs: 4. $\mathrm{G}^{*} \cdot \mathrm{C}^{*}(\mathrm{rWC}) \leftrightarrow \mathrm{G}^{*} \cdot \mathrm{C}\left(\mathrm{w}_{\mathrm{WC}}\right)$ and $5 . \mathrm{G} \cdot \mathrm{C}^{*}{ }_{\mathrm{O} 2}(\mathrm{rWC}) \leftrightarrow \mathrm{G} \cdot \mathrm{C}^{*}\left(\mathrm{w}_{\mathrm{WC}}\right)$ reaction pathways (Fig. 1, 4 and $5)$. First of these base pairs $-\mathrm{G}^{*} \cdot \mathrm{C}^{*}(\mathrm{rWC})$ - tautomerically transforms into the wobble Watson-

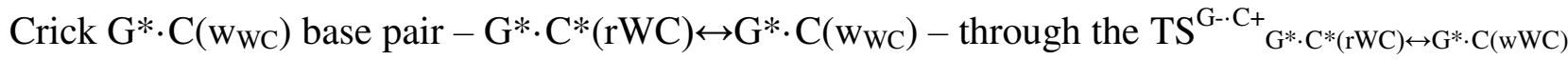
- quasi-orthogonal tight $\mathrm{G}^{-} \cdot \mathrm{C}^{+}$ion pair, which is deprotonated by the $\mathrm{N} 1$ and $\mathrm{N} 2$ sites, protonated by the $\mathrm{O} 6$ site of the $\mathrm{G}$ base and joined by four specific intermolecular contacts - two (C)N4 ${ }^{+} \mathrm{H} \ldots \mathrm{N} 1^{-}(\mathrm{G})$ and $(\mathrm{C}) \mathrm{N} 3^{+} \mathrm{H} . . . \mathrm{N} 1^{-}(\mathrm{G})$ H-bonds, which are locked on the joint $\mathrm{N1}^{-}$atom, and two attractive $(\mathrm{C}) \mathrm{N}^{+}{ }^{+} \ldots \mathrm{N} 2^{-}(\mathrm{G})$ and $(\mathrm{C}) \mathrm{N} 3^{+} \ldots \mathrm{N} 2^{-}(\mathrm{G})$ van der Waals contacts, which are locked on the joint $\mathrm{N}^{-}$atom of the $\mathrm{C}^{-}($Fig. 1,4$)$. Second of the afore mentioned base pairs $-\mathrm{G} \cdot \mathrm{C}^{*}{ }_{\mathrm{O} 2}(\mathrm{rWC})$ 
- tautomerically transforms into the wobble Watson-Crick $\mathrm{G} \cdot \mathrm{C}^{*}\left(\mathrm{w}_{\mathrm{WC}}\right)$ nucleobase pair, for which pyrimidine $\mathrm{C}$ base is exposed into the major groove of DNA accordingly the purine $\mathrm{G}$ base. This $\mathrm{G} \cdot \mathrm{C}^{*} \mathrm{O}_{2}(\mathrm{rWC}) \leftrightarrow \mathrm{G} \cdot \mathrm{C}^{*}\left(\mathrm{~W}_{\mathrm{WC}}\right)$ transition is controlled by the $\mathrm{TS}{ }^{\mathrm{G}-\mathrm{C}+}{ }_{\mathrm{G} \cdot \mathrm{C}^{*} \mathrm{O} 2(\mathrm{rWC}) \leftrightarrow \mathrm{G} \cdot \mathrm{C}^{*}(\mathrm{wWC})}-$ tight $^{-}$ . $\mathrm{C}^{+}$ion pair with quasi-orthogonal geometry, which is deprotonated by the N1 site of the G base and joined by two intermolecular $(\mathrm{C}) \mathrm{O} 2^{+} \mathrm{H} . . . \mathrm{N} 1^{-}(\mathrm{G})$ and $(\mathrm{C}) \mathrm{N} 3^{+} \mathrm{H} . . . \mathrm{N} 1^{-}(\mathrm{G}) \mathrm{H}$-bonds (Fig. 1, 5).

Notably, that tautomeric transition of the $\mathrm{G}^{*} \cdot \mathrm{C}^{*}(\mathrm{rWC})$ base pair into the $\mathrm{G}^{*} \cdot \mathrm{C}\left(\mathrm{w}_{\mathrm{WC}}\right)$ base pair is slower $\left(\Delta \Delta \mathrm{G}_{\mathrm{TS}}=43.13 \mathrm{kcal} \cdot \mathrm{mol}^{-1}\right)$, than transition of the $\mathrm{G} \cdot \mathrm{C}^{*}{ }_{\mathrm{O} 2}(\mathrm{rWC})$ base pair into the $\mathrm{G} \cdot \mathrm{C}^{*}\left(\mathrm{w}_{\mathrm{WC}}\right)$ base pair $\left(\Delta \Delta \mathrm{G}_{\mathrm{TS}}=30.67 \mathrm{kcal} \cdot \mathrm{mol}^{-1}\right)$ since relative Gibbs free energy barrier $\Delta \Delta \mathrm{G}_{\mathrm{TS}}$ of the $\mathrm{G}^{*} \cdot \mathrm{C} *(\mathrm{rWC}) \leftrightarrow \mathrm{G}^{*} \cdot \mathrm{C}\left(\mathrm{w}_{\mathrm{WC}}\right)$ reaction is higher on $12.46 \mathrm{kcal} \cdot \mathrm{mol}^{-1}$ in comparison with the $\mathrm{G} \cdot \mathrm{C} *{ }_{\mathrm{O} 2}(\mathrm{rWC}) \leftrightarrow \mathrm{G} \cdot \mathrm{C} *\left(\mathrm{w}_{\mathrm{WC}}\right)$ reaction $($ Table 1$)$.

Further, we have considered results, which are attractive from the biological point of view and are concerning novel pathways of the tautomerization of the Hoogsteen and reverse Hoogsteen G.C nucleobase pairs with trans-oriented N9H and N1H glycosidic bonds.

4. It was shown that Hoogsteen $\mathrm{G}^{* \mathrm{t}}$. $\mathrm{C}^{*}(\mathrm{H})$ nucleobase pair with cis-oriented $\mathrm{N} 9 \mathrm{H}$ and N1H glycosidic bonds and trans-oriented $\mathrm{O} 6 \mathrm{H}$ hydroxyl group of the $\mathrm{G}^{*}$ base tautomerises into the non-planar reverse wobble Hoogsteen $\mathrm{G}^{* \mathrm{t}} \cdot \mathrm{C}\left(\mathrm{rw}_{\mathrm{H}}\right)$ base pair with trans-oriented $\mathrm{N} 9 \mathrm{H}$ and $\mathrm{N} 1 \mathrm{H}$ glycosidic bonds $-6 . \mathrm{G}^{*^{\mathrm{t}}} \cdot \mathrm{C}^{*}(\mathrm{H}) \leftrightarrow \mathrm{G}^{*^{\mathrm{t}}} \cdot \mathrm{C}\left(\mathrm{rw}_{\mathrm{H}}\right)$ (Fig. 1, 6). This tautomeric transition is controlled by the $\mathrm{TS}^{\mathrm{G}+\cdot \mathrm{C}^{-}}{ }_{\mathrm{G}^{*} t \cdot \mathrm{C}^{*}(\mathrm{H}) \leftrightarrow \mathrm{G}^{*} \cdot \mathrm{C}(\mathrm{rwH})}$, which is tight $\mathrm{G}^{+} \cdot \mathrm{C}^{-}$ion pair with quasi-orthogonal geometry, protonated by the $\mathrm{N} 7$ site of the $\mathrm{G}$ base and stabilized by three intermolecular H-bonds $(\mathrm{G}) \mathrm{O6}^{+} \mathrm{H} . . . \mathrm{N} 3^{-}(\mathrm{C})$ and $(\mathrm{G}) \mathrm{N}^{+} \mathrm{H} . . . \mathrm{N} 3^{-}(\mathrm{C})$, which are focused on the common $\mathrm{N}^{-}$atom, and $(\mathrm{G}) \mathrm{N}^{+} \mathrm{H} . . . \mathrm{N} 4^{-}(\mathrm{G})$. Two last of them are bifurcated from the common N7H group of the G base.

5. At the same time, the Hoogsteen $\mathrm{G}^{*^{\mathrm{t}}}$. $\mathrm{C}^{*}(\mathrm{H})$ nucleobase pair demonstrates high ability to tautomerise into the wobble Hoogsteen $\mathrm{G}^{*} \cdot \mathrm{C}^{*} \mathrm{O}_{2}\left(\mathrm{w}_{\mathrm{H}}\right)$ nucleobase pair through the

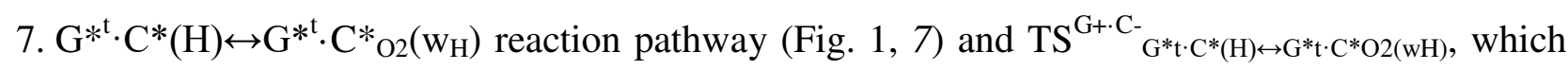
is tight $\mathrm{G}^{+} \cdot \mathrm{C}^{-}$ion pair with quasi-orthogonal geometry, protonated by the $\mathrm{N} 7$ site of the $\mathrm{G}$ base. This structure is stabilized by three intermolecular $\mathrm{H}$-bonds $-(\mathrm{G}) \mathrm{O6}^{+} \mathrm{H} \ldots \mathrm{N}^{-}(\mathrm{C})$ and (G)N7 ${ }^{+} \mathrm{H} \ldots \mathrm{N} 3^{-}(\mathrm{C})$, which are focused on the common N3- atom, and $(\mathrm{G}) \mathrm{N} 7^{+} \mathrm{H} \ldots \mathrm{O} 2^{-}(\mathrm{G})$. Two last of them are bifurcation (Fig. 1, 7).

6. Quite unexpected mechanism defines the tautomerization of the Hoogsteen $G^{* t} \cdot C^{*}(H)$ nucleobase pair into the reverse wobble Hoogsteen $\mathrm{G}^{*^{\mathrm{t}}} \cdot \mathrm{C}^{*} \mathrm{O} 2\left(\mathrm{rw}_{\mathrm{H}}\right)$ structure 8. $\mathrm{G}^{* \mathrm{t}} \cdot \mathrm{C}^{*}(\mathrm{H}) \leftrightarrow \mathrm{G}^{* \mathrm{t}} \cdot \mathrm{C}^{*} \mathrm{O} 2\left(\mathrm{rw}_{\mathrm{H}}\right) \quad$ (Fig. 1, 8). This reaction is controlled by the $\mathrm{TS}^{\mathrm{G}-}$ ${ }^{\mathrm{C}+} \mathrm{G}^{*} \cdot \mathrm{C}^{*}(\mathrm{H}) \leftrightarrow \mathrm{G}^{*} \cdot \mathrm{C}^{*} \mathrm{O} 2(\mathrm{rwH})$, which is tight $\mathrm{G}^{-} \cdot \mathrm{C}^{+}$ion pair with quasi-orthogonal geometry by the participation of the carbanione of the $\mathrm{G}$ base, deprotonated by the $\mathrm{C} 8$ site of the $\mathrm{G}$ base (Fig. 1, 8). This structure is joined by two unexpected intermolecular $(\mathrm{C}) \mathrm{O} 2^{+} \mathrm{H} \ldots \mathrm{C} 8^{-}(\mathrm{G})$ and $(\mathrm{C}) \mathrm{N} 3^{+} \mathrm{H} \ldots \mathrm{C} 8^{-}$ (G) H-bonds, which are focused on the common $\mathrm{C}^{-}$atom (Fig. 1, 8). This one-stage 
8. $\mathrm{G}^{* \mathrm{t}} \cdot \mathrm{C}^{*}(\mathrm{H}) \leftrightarrow \mathrm{G}^{* \mathrm{t}} \cdot \mathrm{C}^{*} \mathrm{O} 2\left(\mathrm{rw}_{\mathrm{H}}\right)$ reaction is quite more rapid $\left(\Delta \Delta \mathrm{G}_{\mathrm{TS}}=59.69 \mathrm{kcal} \cdot \mathrm{mol}^{-1}\right)$, than twostage 9. $\mathrm{G}^{* \mathrm{t}} \cdot \mathrm{C}^{*}(\mathrm{H}) \leftrightarrow \mathrm{G}^{* \mathrm{t}}{ }_{\mathrm{N} 7} \cdot \mathrm{C}^{*}\left(\mathrm{rw}_{\mathrm{H}}\right) \leftrightarrow \mathrm{G}^{* \mathrm{t}} \cdot \mathrm{C}^{*}{ }_{\mathrm{O} 2}\left(\mathrm{rw}_{\mathrm{H}}\right)$ reaction $\left(\Delta \Delta \mathrm{G}_{\mathrm{TS}}=70.71 \mathrm{kcal} \cdot \mathrm{mol}^{-1}\right)($ Fig. 1 , 9), which is controlled by two TSs $-\mathrm{TS}^{\mathrm{G}-\cdot \mathrm{C}+}{ }_{\mathrm{G}^{*} t \cdot \mathrm{C}^{*}(\mathrm{H}) \leftrightarrow \mathrm{G}^{*} \mathrm{tN} 7 \cdot \mathrm{C}^{*}(\mathrm{rwH})}$, which is quasi-orthogonal tight $\mathrm{G}^{-} \cdot \mathrm{C}^{+}$ion pair, deprotonated by the $\mathrm{C} 8$ site of the $\mathrm{G}$ base and joined by two $(\mathrm{C}) \mathrm{O} 2^{+} \mathrm{H} \ldots \mathrm{N} 7^{-}(\mathrm{G})$ and $(\mathrm{C}) \mathrm{N} 3^{+} \mathrm{H} . . . \mathrm{N} 7^{-}(\mathrm{G}) \mathrm{H}$-bonds, which are connected on the common $\mathrm{N7}^{-}$atom, and covalentlybonded $\mathrm{TS}_{\mathrm{G}^{*} \mathrm{tN} 7 \cdot \mathrm{C}^{*}(\mathrm{rwH}) \leftrightarrow \mathrm{G}^{*} \cdot \mathrm{C}^{*} \mathrm{O} 2(\mathrm{rwH})}$, which is joined by the $(\mathrm{G}) \mathrm{N} 7 \mathrm{H} \ldots \mathrm{O} 2(\mathrm{C}) \mathrm{H}-$-bond and $(\mathrm{G}) \mathrm{C} 8$ $\mathrm{H}-\mathrm{N} 3(\mathrm{C})$ covalent bridge.

7. Quite intriguing situation is observed in the case of the tautomerization of the Hoogsteen $\mathrm{G}^{*}{ }_{\mathrm{N} 7} \cdot \mathrm{C}(\mathrm{H})$ base pair, which is high-energy tautomer of the $\mathrm{G}^{*} \cdot \mathrm{C}^{*}(\mathrm{H})$ pair $(\Delta \mathrm{G} / \Delta \mathrm{E}=3.92 / 3.79$ $\mathrm{kcal} \cdot \mathrm{mol}^{-1}$ ), through the $10 . \mathrm{G}^{*}{ }_{\mathrm{N} 7} \cdot \mathrm{C}(\mathrm{H}) \leftrightarrow \mathrm{G}^{* \mathrm{t}} \cdot \mathrm{C}\left(\mathrm{w}_{\mathrm{H}}\right)$ amino reaction pathway (Fig. 1, 10). This

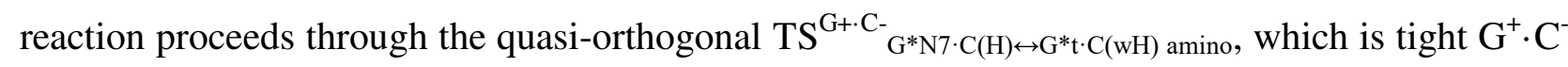
ion pair, involving $\mathrm{G}^{+}$base, protonated at the $\mathrm{N} 7$ site. This structure is stabilized by two intermolecular $(\mathrm{G}) \mathrm{O}^{+} \mathrm{H} \ldots \mathrm{N} 4^{-}(\mathrm{C})$ and $(\mathrm{G}) \mathrm{N}^{+} \mathrm{H} . . \mathrm{N} 4^{-}(\mathrm{C}) \mathrm{H}$-bonds, which are focused on the common $\mathrm{N}^{-}$atom of the $\mathrm{C}$ base. Product of this reaction - wobble Hoogsteen $\mathrm{G}^{*} \cdot \mathrm{C}\left(\mathrm{w}_{\mathrm{H}}\right)$ amino base pair is significantly non-planar and has cis-orientation of the $\mathrm{N} 9 \mathrm{H}$ and $\mathrm{N} 1 \mathrm{H}$ glycosidic bonds, similarly to the starting $\mathrm{G}^{*}{ }_{\mathrm{N} 7} \cdot \mathrm{C}(\mathrm{H})$ base pair (Fig. 1, 10).

8. The $\mathrm{G}^{* \mathrm{t}} \cdot \mathrm{C} *(\mathrm{rH})$ nucleobase pair, which has reverse Hoogsteen configuration, tautomerises into the $\mathrm{G}^{*}{ }_{\mathrm{N} 7} \cdot \mathrm{C}^{*}\left(\mathrm{w}_{\mathrm{H}}\right)$ and $\mathrm{G}^{*}{ }_{\mathrm{N} 7} \cdot \mathrm{C}^{*}\left(\mathrm{w}_{\mathrm{H}}\right)$ base pairs with wobble Hoogsteen configuration through the quasi-orthogonal $\mathrm{TS}^{\mathrm{G}-\cdot \mathrm{C}+}{ }_{\mathrm{G}^{*} \cdot \mathrm{C}^{*}(\mathrm{rH}) \leftrightarrow \mathrm{G}^{*} \mathrm{~N} 7 \cdot \mathrm{C}^{*}(\mathrm{wH})}$ and $\mathrm{TS}^{\mathrm{G}-}$ ${ }^{C}+{ }_{\mathrm{G}^{*} \cdot \mathrm{C} \cdot \mathrm{C}(\mathrm{rH}) \leftrightarrow \mathrm{G}^{*} \mathrm{t} \cdot \mathrm{C}(\mathrm{wH})}$ transition states, respectively, which are tight $\mathrm{G}^{-} \cdot \mathrm{C}^{+}$ion pairs. These transitions occur through two pathways, which are different as from the topological, so from the energetical points of view $-11 . G^{* t} \cdot C^{*}(r H) \leftrightarrow G^{*}{ }_{N 7} \cdot C^{*}\left(w_{H}\right)$ and $12 . G^{* t} \cdot C^{*}(r H) \leftrightarrow G^{* t} \cdot C\left(w_{H}\right)($ Fig. 1,11 and 12). First of the reactions $-11 . \mathrm{G}^{*} \cdot \mathrm{C}^{*}(\mathrm{rH}) \leftrightarrow \mathrm{G}^{*}{ }_{\mathrm{N} 7} \cdot \mathrm{C}^{*}\left(\mathrm{w}_{\mathrm{H}}\right)$ is controlled by the $\mathrm{TS}^{\mathrm{G}-}$ ${ }^{\mathrm{C}+}{ }_{\mathrm{G}^{*} \mathrm{t} \cdot \mathrm{C}^{*}(\mathrm{rH}) \leftrightarrow \mathrm{G}^{*} \mathrm{~N} 7 \cdot \mathrm{C}^{*}(\mathrm{wH})}$, which contains $\mathrm{G}^{-}$, deprotonated by the $\mathrm{O} 6$ site, and is stabilized by the participation of the four specific intermolecular interactions - two (C)O2 ${ }^{+} \mathrm{H} \ldots \mathrm{N}^{-}(\mathrm{G})$ and (C)N3 ${ }^{+} \mathrm{H} \ldots \mathrm{N}^{-}(\mathrm{G}) \mathrm{H}$-bonds, focused on the common $\mathrm{N7}^{-}$atom of the $\mathrm{G}$ base, and two attractive van der Waals contacts $-(\mathrm{G}) \mathrm{O6}^{-} \ldots \mathrm{O}^{+}(\mathrm{C})$ and $(\mathrm{G}) \mathrm{O6}^{-} \ldots \mathrm{N} 3^{+}(\mathrm{C})$, focused on the common $6^{-}$ atom of the $\mathrm{G}$ base. First of the van der Waals contacts $-(\mathrm{G}) \mathrm{O6}^{-} \ldots \mathrm{O} 2^{+}(\mathrm{C})-$ is the shortest $(2.676$ $\AA$ ) among all others considered here (Fig. 1, 11). Second $12 . \mathrm{G}^{* \mathrm{t}} \cdot \mathrm{C}^{*}(\mathrm{rH}) \leftrightarrow \mathrm{G}^{* \mathrm{t}} \cdot \mathrm{C}\left(\mathrm{w}_{\mathrm{H}}\right)$ reaction is controlled by the $\mathrm{TS}^{\mathrm{G}-\cdot \mathrm{C}+} \mathrm{G}^{*} \cdot \mathrm{C} \cdot \mathrm{C}(\mathrm{rH}) \leftrightarrow \mathrm{G}^{*} \mathrm{t} \cdot \mathrm{C}(\mathrm{wH})$, which is tight $\mathrm{G}^{-} \cdot \mathrm{C}^{+}$ion pair by the participation of the $\mathrm{G}^{-}$, deprotonated at the $\mathrm{C} 8$ site and containing carbanione of the $\mathrm{G}$ base. This structure is stabilized by two unusual intermolecular (C)N4 ${ }^{+} \mathrm{H} . . . \mathrm{C} 8^{-}(\mathrm{G})$ and $(\mathrm{C}) \mathrm{N} 3^{+} \mathrm{H} . . . \mathrm{C} 8^{-}(\mathrm{G}) \mathrm{H}$-bonds, which are focused on the common $\mathrm{C}^{-}$atom of the $\mathrm{G}$ base (Fig. 1, 12).

9. Reverse Hoogsteen $\mathrm{G}^{* \mathrm{t}}{ }_{\mathrm{N} 7} \cdot \mathrm{C}(\mathrm{rH})$ nucleobase pair, which is high energy tautomer of the reverse Hoogsteen $\mathrm{G}^{* \mathrm{t}} \cdot \mathrm{C}^{*}(\mathrm{rH})$ nucleobase pair $\left(\Delta \mathrm{G} / \Delta \mathrm{E}=23.70 / 23.36 \mathrm{kcal} \cdot \mathrm{mol}^{-1}\right)$, tautomerises 
into the wobble Hoogsteen $\mathrm{G}^{* \mathrm{t}} \cdot \mathrm{C}\left(\mathrm{w}_{\mathrm{H}}\right)$ nucleobase pair, involving carbanione of the $\mathrm{G}$ base, by two-stage reaction $-13 . \mathrm{G}^{* \mathrm{t}} \mathrm{N7} \cdot \mathrm{C}(\mathrm{rH}) \leftrightarrow \mathrm{G}^{* \mathrm{t}} \mathrm{N}^{\circ} \mathrm{C}^{*}\left(\mathrm{w}_{\mathrm{H}}\right) \leftrightarrow \mathrm{G}^{* \mathrm{t}} \cdot \mathrm{C}\left(\mathrm{w}_{\mathrm{H}}\right)($ Fig. 1, 13).

First stage $13 . \mathrm{G}^{* \mathrm{t}}{ }_{\mathrm{N} 7} \cdot \mathrm{C}(\mathrm{rH}) \leftrightarrow \mathrm{G}^{* \mathrm{t}}{ }_{\mathrm{N} 7} \cdot \mathrm{C}^{*}\left(\mathrm{w}_{\mathrm{H}}\right)$ is controlled by the quasi-orthogonal $\mathrm{TS}^{\mathrm{G}-}$ ${ }^{\mathrm{C}+}{ }_{\mathrm{G}}^{*} \mathrm{tN} 7 \cdot \mathrm{C}(\mathrm{rH}) \leftrightarrow \mathrm{G}^{*} \mathrm{tN} 7 \cdot \mathrm{C}^{*}(\mathrm{wH})$, which is tight $\mathrm{G}^{-} \cdot \mathrm{C}^{+}$ion pair by the participation of the carbanione of the $\mathrm{G}$ base, deprotonated by the $\mathrm{C} 8$ site and joined by the participation of two intermolecular (C)N4 ${ }^{+} \mathrm{H} \ldots \mathrm{N} 7^{-}(\mathrm{G})$ and $(\mathrm{C}) \mathrm{N} 3^{+} \mathrm{H} \ldots \mathrm{N} 7^{-}(\mathrm{G}) \mathrm{H}$-bonds, which are focused on the common $\mathrm{N}^{-}$atom of the $G$ base.

Second stage $13 . \mathrm{G}^{* \mathrm{t}}{ }_{\mathrm{N} 7} \cdot \mathrm{C}^{*}\left(\mathrm{w}_{\mathrm{H}}\right) \leftrightarrow \mathrm{G}^{* \mathrm{t}} \cdot \mathrm{C}\left(\mathrm{w}_{\mathrm{H}}\right)$ represents double proton transfer in the wobble Hoogsteen $\mathrm{G}^{* \mathrm{t}}{ }_{\mathrm{N} 7} \cdot \mathrm{C}^{*}\left(\mathrm{w}_{\mathrm{H}}\right)$ base pair, which occurs through the covalently-bonded $\mathrm{TS}_{\mathrm{G}^{*} \mathrm{tN} 7 \cdot \mathrm{C} *(\mathrm{wH}) \leftrightarrow \mathrm{G}^{*} \cdot \mathrm{C}(\mathrm{wH})}$, stabilized by the $(\mathrm{G}) \mathrm{C} 8-\mathrm{H}-\mathrm{N} 3(\mathrm{C})$ covalent bridge and $(\mathrm{G}) \mathrm{N} 7 \mathrm{H} . . \mathrm{N} 4(\mathrm{C}) \mathrm{H}-$ bond, leading to the wobble Hoogsteen $\mathrm{G}^{*} \cdot \mathrm{C}\left(\mathrm{w}_{\mathrm{H}}\right)$ nucleobase pair (Fig. 1, 13). Formed $\mathrm{G}^{* \mathrm{t}} \cdot \mathrm{C}\left(\mathrm{w}_{\mathrm{H}}\right)$ nucleobase pair is stabilized by the participation of two intermolecular (C)N4H...N7(G) and (G)C8H...N3(C) H-bonds.

10. Finally, for the first time it was observed quite complicated mechanism of the tautomeric transformation of the reverse wobble Hoogsteen $\mathrm{G}^{*}{ }_{\mathrm{N} 7} \cdot \mathrm{C}^{*}\left(\mathrm{rw}_{\mathrm{H}}\right)$ nucleobase pair into the reverse wobble Hoogsteen $\mathrm{G}^{*} \cdot \mathrm{C}\left(\mathrm{rw}_{\mathrm{H}}\right)$ nucleobase pair $-14 . \mathrm{G}^{*}{ }_{\mathrm{N} 7} \cdot \mathrm{C}^{*}\left(\mathrm{rw}_{\mathrm{H}}\right) \leftrightarrow \mathrm{G}^{*}{ }_{\mathrm{N} 7} \cdot \mathrm{C}^{*}\left(\mathrm{rw}_{\mathrm{H}}\right)_{\text {perp }} \leftrightarrow \mathrm{G}^{-}$ $\cdot \mathrm{C}^{+}\left(\mathrm{rw}_{\mathrm{H}}\right) \leftrightarrow \mathrm{G}^{* \mathrm{t}} \cdot \mathrm{C}\left(\mathrm{rw}_{\mathrm{H}}\right)$ (Fig. 1, 14). This reaction is not accompanied by the changing of the mutual orientation of the $\mathrm{N} 9 \mathrm{H}$ and $\mathrm{N} 1 \mathrm{H}$ glycosidic bonds.

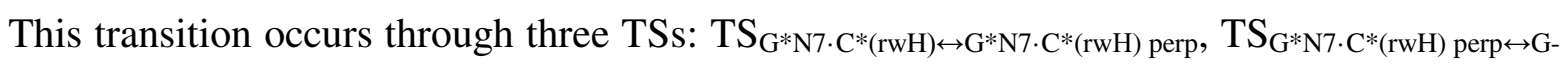
$\cdot \mathrm{C}+(\mathrm{rwH}), \mathrm{TS}_{\mathrm{G}-\mathrm{C}+(\mathrm{rwH}) \leftrightarrow \mathrm{G}^{*} \cdot \mathrm{C}(\mathrm{rwH})}^{\mathrm{G}+{ }_{\mathrm{C}}}$ and two dynamically stable intermediates: reverse wobble Hoogsteen $\mathrm{G}^{*}{ }_{\mathrm{N} 7} \cdot \mathrm{C}^{*}\left(\mathrm{rw}_{\mathrm{H}}\right)_{\text {perp }}$ nucleobase pair and reverse wobble Hoogsteen $\mathrm{G}^{-} \cdot \mathrm{C}^{+}\left(\mathrm{rw}_{\mathrm{H}}\right)$ ion pair, which are significantly non-planar structures (Fig. 1, 14). First among TSs $\mathrm{TS}_{\mathrm{G}^{*} \mathrm{~N} 7 \cdot \mathrm{C}^{*}(\mathrm{rwH}) \leftrightarrow \mathrm{G}^{*} \mathrm{~N} 7 \cdot \mathrm{C} *(\mathrm{rwH}) \text { perp }}$ is responsible for the conformational $\mathrm{G}^{*}{ }_{\mathrm{N} 7} \cdot \mathrm{C}^{*}\left(\mathrm{rw}_{\mathrm{H}}\right) \leftrightarrow \mathrm{G}^{*}{ }_{\mathrm{N} 7} \cdot \mathrm{C}^{*}\left(\mathrm{rw}_{\mathrm{H}}\right)_{\text {perp }}$ transition, second among $\mathrm{TSs}-\mathrm{TS}_{\mathrm{G}} \mathrm{N}^{\mathrm{N} \cdot \mathrm{C} \cdot(\mathrm{rwH}) \text { perp } \leftrightarrow \mathrm{G}-\mathrm{C}+(\mathrm{rwH})}$ is responsible for the $\mathrm{G}^{*}{ }_{\mathrm{N} 7} \cdot \mathrm{C}^{*}\left(\mathrm{rw}_{\mathrm{H}}\right)_{\text {perp }} \leftrightarrow \mathrm{G}^{-} \cdot \mathrm{C}^{+}\left(\mathrm{rw}_{\mathrm{H}}\right)$ single proton transfer and third among TSs $\mathrm{TS}^{\mathrm{G}-\mathrm{C}+}{ }_{\mathrm{G}-\mathrm{C}+(\mathrm{rwH}) \leftrightarrow \mathrm{G}^{*} \cdot \mathrm{C}(\mathrm{rwH})}$ leads to the formation of the reverse wobble Hoogsteen $\mathrm{G}^{* \mathrm{t}} \cdot \mathrm{C}\left(\mathrm{rw}_{\mathrm{H}}\right)$

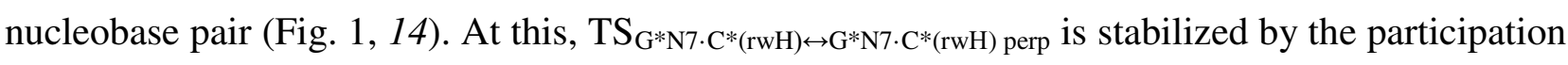
of the intermolecular $(\mathrm{G}) \mathrm{N} 7 \mathrm{H} \ldots \mathrm{N} 4(\mathrm{C}) \mathrm{H}$-bond and attractive $(\mathrm{G}) \mathrm{O} 6 \ldots \mathrm{N} 3(\mathrm{C})$ van der Waals

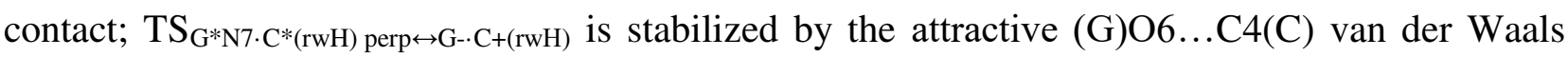

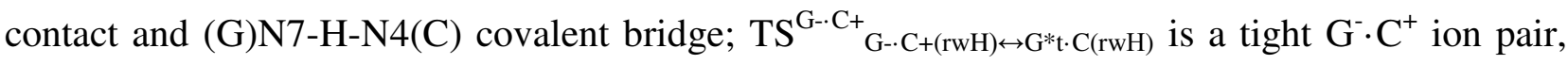
deprotonated by the $\mathrm{N} 7$ site of the $\mathrm{G}$ base, and stabilized by two intermolecular $(\mathrm{C}) \mathrm{N} 4^{+} \mathrm{H} \ldots \mathrm{N} 7^{-}(\mathrm{G})$ and $(\mathrm{C}) \mathrm{N}^{+} \mathrm{H} . . \mathrm{N} 7^{-}(\mathrm{G}) \mathrm{H}$-bonds, focused on the common $\mathrm{N7}^{-}$atom, and attractive (G)O6 ... $\mathrm{N}^{+}(\mathrm{C})$ van der Waals contact. The $\mathrm{G}^{-} \cdot \mathrm{C}^{+}\left(\mathrm{rw}_{\mathrm{H}}\right)$ ion pair with quasi-orthogonal geometry is stabilized by the participation of two intermolecular $(\mathrm{C}) \mathrm{N}^{+}{ }^{+} \mathrm{H} \ldots \mathrm{N}^{-}(\mathrm{G})$ and $(\mathrm{C}) \mathrm{N} 3^{+} \mathrm{H}_{\text {... N7 }}(\mathrm{G}) \mathrm{H}^{-}$ bonds, focused on the common $\mathrm{N}^{-}$atom, and attractive $(\mathrm{G}) \mathrm{O6}^{-} \ldots \mathrm{C}^{+}(\mathrm{C})$ van der Waals contact. 
Now it would be shortly considered non-planar deformation of the $\mathrm{G}$ and $\mathrm{C}$ nucleotide bases, accompanying investigated here processes. Despite the structural softness of the $\mathrm{G}$ and $\mathrm{C}$ bases for bending [20,21], cycles of the $G$ and $C$ bases remain planar even at the TSs of the transitions. The largest orientational deformation occurs in the exocyclic fragments $-\mathrm{NH}_{2}$ amino groups and $\mathrm{OH}$ hydroxyl groups. Thus, in particular, piramidality of the $\mathrm{NH}_{2}$ amino group of the $\mathrm{G}$ base significantly increases at the transformation into the $\mathrm{G}^{-} \cdot \mathrm{C}^{+}$ion pair - it could be explained by the weakness of the electronic conjugation between the $\mathrm{N} 2$ amino atom and $\boldsymbol{\pi}$-electron system of the ring of the base at its deprotonation. Also, it is observed pyramidalization of the $\mathrm{NH}_{2}$ amino group of the protonated $\mathrm{C}$ base. The largest changes in the orientation of the exocyclic groups were observed at the $\mathrm{TS}^{\mathrm{G}-\cdot \mathrm{C}+}{ }_{\mathrm{G}^{*} \cdot \mathrm{C} \cdot \mathrm{C}(\mathrm{rH}) \leftrightarrow \mathrm{G}^{*} \mathrm{~N} 7 \cdot \mathrm{C}^{*}(\mathrm{wH})}$ (Fig. 1, 11).

Last, but not least. Joining results, which have been obtained in this work, with the data, which have been received in our previous works [20,21], we came to the conclusion, that classical Watson-Crick G.C(WC) nucleobase pair with cis-oriented glycosidic bonds transforms to two reverse Watson-Crick $\mathrm{G}^{*} \cdot \mathrm{C}^{*}(\mathrm{rWC})$ and $\mathrm{G} \cdot \mathrm{C}^{*}{ }_{\mathrm{O} 2}(\mathrm{rWC})$ nucleobase pairs with trans-oriented glycosidic bonds, which are in tautomeric equilibrium between each other, by four different

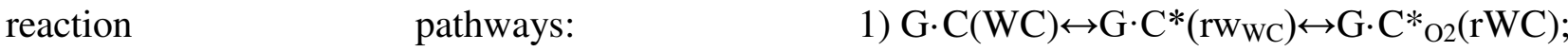

2) $\mathrm{G} \cdot \mathrm{C}(\mathrm{WC}) \leftrightarrow \mathrm{G}^{*} \cdot \mathrm{C}^{*}(\mathrm{WC}) \leftrightarrow \mathrm{G} \cdot \mathrm{C}^{*}\left(\mathrm{rw}_{\mathrm{WC}}\right) \leftrightarrow \mathrm{G} \cdot \mathrm{C}^{*} \mathrm{O} 2(\mathrm{rWC})$;

3) $\mathrm{G} \cdot \mathrm{C}(\mathrm{WC}) \leftrightarrow \mathrm{G}^{*} \cdot \mathrm{C}\left(\mathrm{w}_{\mathrm{WC}}\right) \leftrightarrow \mathrm{G}^{*} \cdot \mathrm{C}^{*}(\mathrm{rWC})$; 4) $\mathrm{G} \cdot \mathrm{C}(\mathrm{WC}) \leftrightarrow \mathrm{G}^{*} \mathrm{C}^{*}\left(\mathrm{~W}_{\mathrm{WC}}\right) \leftrightarrow \mathrm{G} \cdot \mathrm{C}^{*} \mathrm{O} 2(\mathrm{rWC})$.

Similarly, it has been proven that Hoogsteen $\mathrm{G}^{*}{ }^{\mathrm{t}} \cdot \mathrm{C}^{*}(\mathrm{H})$ and $\mathrm{G}^{*}{ }_{\mathrm{N} 7} \cdot \mathrm{C}(\mathrm{H})$ nucleobase pairs transform to three reverse Hoogsteen $\mathrm{G}^{* \mathrm{t}} \cdot \mathrm{C} *(\mathrm{rH}), \mathrm{G}^{* \mathrm{t}} \cdot \mathrm{C}^{*}{ }_{\mathrm{O} 2}(\mathrm{rH})$ and $\mathrm{G}^{* \mathrm{t}}{ }_{\mathrm{N} 7} \cdot \mathrm{C}(\mathrm{rH})$ nucleobase pairs through six different pathways: 1$) G^{* t} \cdot C^{*}(H) \leftrightarrow G^{* t} \cdot C\left(r w_{H}\right) \leftrightarrow G^{* t} \cdot C^{*}(r H)$; 2) $\mathrm{G}^{* \mathrm{t}} \cdot \mathrm{C}^{*}(\mathrm{H}) \leftrightarrow \mathrm{G}^{* \mathrm{t}} \cdot \mathrm{C}^{*} \mathrm{O} 2\left(\mathrm{rw}_{\mathrm{H}}\right) \leftrightarrow \mathrm{G}^{* \mathrm{t}} \cdot \mathrm{C}^{*} \mathrm{O} 2(\mathrm{rH})$;

3) $\mathrm{G}^{* \mathrm{t}} \cdot \mathrm{C}^{*}(\mathrm{H}) \leftrightarrow \mathrm{G}^{* \mathrm{t}}{ }_{\mathrm{N} 7} \cdot \mathrm{C}^{*}\left(\mathrm{rw}_{\mathrm{H}}\right) \leftrightarrow \mathrm{G}^{* \mathrm{t}} \cdot \mathrm{C}^{*} \mathrm{O} 2^{\mathrm{O}}\left(\mathrm{rw}_{\mathrm{H}}\right) \leftrightarrow \mathrm{G}^{* \mathrm{t}} \cdot \mathrm{C}^{*} \mathrm{O} 2(\mathrm{rH})$;

4) $\mathrm{G}^{*}{ }_{\mathrm{N} 7} \cdot \mathrm{C}(\mathrm{H}) \leftrightarrow \mathrm{G}^{*}{ }_{\mathrm{N} 7} \cdot \mathrm{C}^{*}\left(\mathrm{w}_{\mathrm{H}}\right) \leftrightarrow \mathrm{G}^{* \mathrm{t}} \cdot \mathrm{C}^{*}(\mathrm{rH}) ; \quad$ 5) $\mathrm{G}^{* \mathrm{t}} \cdot \mathrm{C}^{*}(\mathrm{H}) \leftrightarrow \mathrm{G}^{* \mathrm{t}} \cdot \mathrm{C}\left(\mathrm{w}_{\mathrm{H}}\right) \leftrightarrow \mathrm{G}^{* \mathrm{t}} \cdot \mathrm{C}^{*}(\mathrm{rH})$;

6) $\mathrm{G}^{* \mathrm{t}} \cdot \mathrm{C} *(\mathrm{H}) \leftrightarrow \mathrm{G}^{* \mathrm{t}}{ }_{\mathrm{N} 7} \cdot \mathrm{C}^{*}\left(\mathrm{w}_{\mathrm{H}}\right) \leftrightarrow \mathrm{G}^{* \mathrm{t}}{ }_{\mathrm{N} 7} \cdot \mathrm{C}(\mathrm{rH})$.

Attractiveness of these tautomeric transitions, which are accompanied by the changing of the mutual orientation of the glycosidic bonds of the bases from cis- on trans-orientation, consists in the fact that they have quite high energy of interaction at the TSs $\left(\Delta \mathrm{G}_{\mathrm{int}}>100 \mathrm{kcal} \cdot \mathrm{mol}^{-1}\right)$ and thus can reorganize stacking of the neighboring base pairs and significantly change the conformation of the sugar-phosphate residues. In other words, they are perfect pretendents on the role of the drivers of the transition of the DNA and RNA molecules from the states with anti-parallel strands into the duplexes with parallel strands [45]. 


\section{CONCLUSIONS.}

In this study it was performed careful QM/QTAIM investigation, aimed to identify all possible quantum mechanisms of the tautomerization of the classical G.C nucleobase pairs as their intrinsic property, which enable to make the following conclusions.

It was revealed for the first time novel physico-chemical mechanisms of the conformationally-tautomeric transitions of the four biologically-important configurations of the G.C nucleobase pairs - Watson-Crick G.C(WC), reverse Watson-Crick G.C(rWC), Hoogsteen $\mathrm{G} \cdot \mathrm{C}(\mathrm{H})$ and reverse Hoogsteen $\mathrm{G} \cdot \mathrm{C}(\mathrm{rH})$, occuring through the quasi-orthogonal TSs, which represent tight $\mathrm{G}^{+} \cdot \mathrm{C}^{-} / \mathrm{G}^{-} \cdot \mathrm{C}^{+}$ion pairs, joined by at least two anti-parallel H-bonds, closed on a common $\mathrm{N}^{-} / \mathrm{C}^{-}$endocyclic atom carrying negative charge.

Existence of the two neighboring anti-parallel intermolecular H-bonds in the base pair is a necessary and sufficient condition of the existance of such tautomeric transformations. In this case tautomerization realises exclusively by the participation of the atoms, involved in these above mentioned H-bonds.

Revealed pathways of the quantum tautomerization are controlled by the quite complicated potential energy hypersurface, which have been obtained by the base pairs in the course of the long-term evolution. However, these transitions could not be predicted by the qualitative stereochemical analysis without thorough QM/QTAIM research. Every of each transition has very unique behavior and could not be generalized with the aim of their extension on others pairs of nucleotide bases.

Biological attractiveness of the detected tautomeric transformations, which are accompanied by the changing of the mutual orientation of the glycosidic bonds of the bases on the opposite (cis $\leftrightarrow$ trans) consist in the fact that they can determine tautomerically-conformational transitions both in DNA, so in RNA molecules, leading to the changing of the mutual orientation of their sugar-phosphate residues - from the anti-parallel on the parallel and vice versa. Moreover, they could be responsible for the supporting of the unique spatial structures of these biological macromolecules in the process of their functioning.

\section{Declarations.}

Funding: Not applicable.

Conflicts of interest/Competing interests: Not applicable.

Availability of data and material: Not applicable.

Code availability: Gaussian'09 program package - gaussian.com; AIMAll program package http://aim.tkgristmill.com/. 
Authors' contributions: OB - idea formulation, setting of the task, calculation of the data, building of the graphs, data extrapolation, preparing, and proofreading of the draft of the manuscript. AM idea formulation, calculation of the data, preparing, and proofreading of the draft of the manuscript. DH - idea formulation, preparing, and proofreading of the draft of the manuscript. All authors contributed to the article and approved the submitted version. 


\section{REFERENCES.}

1. Crick, F.H.C., Watson, J.D. The complementary structure of deoxyribonucleic acid. Proc. Roy. Soc., 1954, A223, 80-96.

2. Löwdin, P-O. Proton tunneling in DNA and its biological implications. Rev. Mod. Phys., 1963, 35, 724-732.

3. Brovarets', O.O., Tsiupa, K.S., Hovorun, D.M. Where quantum biochemistry meets structural bioinformatics: excited conformationally-tautomeric states of the classical A-T DNA base pair. DNA - Damages and Repair Mechanisms / Ed. by Payam Behzadi. IntechOpen: London, United Kingdom, 2021. ISBN 978-1-83881-094-8.

4. Brovarets', O.O., Hovorun, D.M. Renaissance of the tautomeric hypothesis of the spontaneous point mutations in DNA: new ideas and computational approaches. Mitochondrial DNA - New Insights / Ed. by Herve Seligmann, IntechOpen: London, United Kingdom, 2018. ISBN 978-95351-6167-7.

5. Samijlenko, S.P., Krechkivska, O.M., Kosach, D.A., Hovorun, D.M. Transitions to high tautomeric states can be induced in adenine by interactions with carboxylate and sodium ions: DFT calculation data. J. Mol. Struct., 2004, 708, 97-104.

6. Markova, N., Pejov, L., Enchev, V. Hybrid MC/QC simulations of water-assisted proton transfer in nucleosides. Guanosine and its analog acyclovir. J. Biomol. Struct. Dynam., 2017, 36, 1168-1188.

7. Brovarets', O.O., Hovorun, D.M. A new era of the prototropic tautomerism of the quercetin molecule: A QM/QTAIM computational advances. J. Biomol. Struct. Dynam., 2020, 38, 47744800.

8. Pospisil, P., Ballmer, P., Scapozza, L., Folkers, G. Tautomerism in computer-aided drug design. J. Rec. Sign. Trans., 2003, 23, 361-371.

9. Dhaked, D.K., Ihlenfeldt, W.-D., Patel, H., Delannee, V., Nicklaus, M.C. Toward a comprehensive treatment of tautomerism in chemoinformatics including in InChI V2. J. Chem. Inf. Model., 2020, 60, 1253-1275.

10. Dobosz, R., Kolehmainen, E., Valkonen, A., Ośmiałowski, B., Gawinecki, R. Tautomeric preferences of phthalones and related compounds. Tetrahedron, 2007, 63, 9172-9178.

11. Larina, L.I. Tautomerism and structure of azoles. Adv. Het. Chem., 2018, 233-321.

12. Brovarets', O.O., Voiteshenko, I.S., Hovorun, D.M. Physicochemical profiles of the wobble $\leftrightarrow$ Watson-Crick $\quad \mathrm{G}^{*} \cdot 2 \mathrm{AP}(\mathrm{w}) \leftrightarrow \mathrm{G} \cdot 2 \mathrm{AP}(\mathrm{WC}) \quad$ and $\quad \mathrm{A} \cdot 2 \mathrm{AP}(\mathrm{w}) \leftrightarrow \mathrm{A}^{*} \cdot 2 \mathrm{AP}(\mathrm{WC})$ tautomerisations: A QM/QTAIM comprehensive survey. Phys. Chem. Chem. Phys., 2018, 20, 623-636.

13. Gad, S.F., El-Demerdash, S.H., El-Mehasseb, I.M., El-Nahas, A.M. Structure, stability and conversions of tautomers and rotamers of azulene-based uracil analogue. J. Mol. Struct., 2019, 1182, 271-282.

14. Brovarets', O.O., Tsiupa, K.S., Hovorun, D.M. Non-dissociative structural transitions of the Watson-Crick and reverse Watson-Crick A-T DNA base pairs into the Hoogsteen and reverse Hoogsteen forms. Sci. Repts., 2018, 8, 10371.

15. Erdmann, V.A., Markiewicz, W.T., Barciszewski, J. Chemical biology of nucleic acids. Heidelberg: Springer, 2014.

16. Brovarets', O.O., Pérez-Sánchez, H.E., Hovorun, D.M. Structural grounds for the 2aminopurine mutagenicity: A novel insight into the old problem of the replication errors. RSC Adv., 2016, 6, 99546-99557. 
17. Brovarets', O.O., Hovorun, D.M. Quantum dancing of the wobble G.T(U/ $\left.{ }^{5 \mathrm{Br}} \mathrm{U}\right)$ nucleobase pairs and its biological roles. Chem. Phys., 2020, 1, 100006.

18. Brovarets', O.O., Hovorun, D.M. Tautomeric transition between wobble A.C DNA base mispair and Watson-Crick-like A.C $\mathrm{C}^{*}$ mismatch: Microstructural mechanism and biological significance. Phys. Chem. Chem. Phys., 2015, 17, 15103-15110.

19. Brovarets', O.O., Hovorun, D.M. Novel physico-chemical mechanism of the mutagenic tautomerisation of the Watson-Crick-like A.G and C.T DNA base mispairs: A quantum-chemical picture. RSC Adv., 2015, 5, 66318-66333.

20. Brovarets', O.O., Oliynyk, T.A., Hovorun, D.M. Novel tautomerisation mechanisms of the biologically important conformers of the reverse Löwdin, Hoogsteen, and reverse Hoogsteen $\mathrm{G}^{*}$. $\mathrm{C}^{*}$ DNA base pairs via proton transfer: a quantum-mechanical survey. Front. Chem., 2019, 7, 597.

21. Brovarets', O.O., Muradova, A., Hovorun, D.M. A quantum-mechanical looking behind the scene of the classic G.C nucleobase pairs tautomerization. Front. Chem., 2020, 8, 574454.

22. Brovarets', O.O., Muradova, A., Hovorun, D.M. Atomistic mechanisms of the tautomerization of the G.C base pairs through the proton transfer: Quantum-chemical survey. J. Mol. Model., 2021, (in press).

23. Tirado-Rives, J., \& Jorgensen, W.L. Performance of B3LYP Density Functional Methods for a large set of organic molecules, J. Chem. Theory Comput., 2008, 4, 297-306.

24. Parr, R.G., \& Yang, W. Density-functional theory of atoms and molecules. Oxford: Oxford University Press, 1989.

25. Lee, C., Yang, W., \& Parr, R.G. Development of the Colle-Salvetti correlation-energy formula into a functional of the electron density, Phys. Rev. B., 1988, 37, 785-789.

26. Hariharan, P.C., \& Pople, J.A. The influence of polarization functions on molecular orbital hydrogenation energies, Theor. Chim. Acta, 1973, 28, 213-222.

27. Krishnan, R., Binkley, J.S., Seeger, R., \& Pople, J.A. Self-consistent molecular orbital methods. XX. A basis set for correlated wave functions, J. Chem. Phys., 1980, 72, 650-654.

28. Frisch, M.J., Trucks, G.W., Schlegel, H.B., Scuseria, G.E., Robb, M.A., \& Cheeseman, J.R., ... Pople, J.A. (2010). GAUSSIAN 09 (Revision B.01). Wallingford CT: Gaussian Inc.

29. Matta, C.F. How dependent are molecular and atomic properties on the electronic structure method? Comparison of Hartree-Fock, DFT, and MP2 on a biologically relevant set of molecules, J. Comput. Chem., 2010, 31, 1297-1311.

30. Brovarets', O.O., Zhurakivsky, R.O., Hovorun, D.M. Does the tautomeric status of the adenine bases change upon the dissociation of the $A^{*} \cdot A_{\text {syn }}$ Topal-Fresco DNA mismatch? A combined QM and QTAIM atomistic insight. Phys. Chem. Chem. Phys., 2014, 16, 3715-3725.

31. Palafox, M.A. Molecular structure differences between the antiviral nucleoside analogue 5iodo-2 2 -deoxyuridine and the natural nucleoside 2 -deoxythymidine using MP2 and DFT methods: conformational analysis, crystal simulations, DNA pairs and possible behavior. J. Biomol. Struct. \& Dynam., 2014, 32, 831-851.

32. El-Sayed, A.A., Tamara Molina, A., Alvarez-Ros, M.C., Alcolea Palafox, M. Conformational analysis of the anti-HIV Nikavir prodrug: comparisons with AZT and thymidine, and establishment of structure-activity relationships/tendencies in other 6'-derivatives. J. Biomol. Struct. \& Dynam., 2015, 33, 723-748.

33. Peng, C., Ayala, P.Y., Schlegel, H.B., \& Frisch, M.J. Using redundant internal coordinates to optimize equilibrium geometries and transition states. J. Comput. Chem., 1996, 17, 49-56. 
34. García-Moreno, B.E., Dwyer, J.J., Gittis, A.G., Lattman, E.E., Spencer D.S., \& Stites, W.E. Experimental measurement of the effective dielectric in the hydrophobic core of a protein. Biophys. Chem., 1997, 64, 211-224.

35. Bayley, S.T. The dielectric properties of various solid crystalline proteins, amino acids and peptides. Trans. Faraday Soc., 1951, 47, 509-517.

36. Frisch, M.J., Head-Gordon, M., \& Pople, J.A. Semi-direct algorithms for the MP2 energy and gradient. Chem. Phys. Lett., 1990, 166, 281-289.

37. Kendall, R.A., Dunning, Jr., T.H., \& Harrison, R.J. Electron affinities of the first-row atoms revisited. Systematic basis sets and wave functions. J. Chem. Phys., 1992, 96, 6796-6806.

38. Bader, R.F.W. Atoms in molecules: A quantum theory. Oxford: Oxford University Press, 1990.

39. Matta, C.F., Hernández-Trujillo, J. Bonding in polycyclic aromatic hydrocarbons in terms of the electron density and of electron delocalization. J. Phys. Chem. A, 2003, 107, 7496-7504.

40. Matta, C.F., Castillo, N., Boyd, R.J. Atomic contributions to bond dissociation energies in aliphatic hydrocarbons. J. Chem. Phys., 2006, 125, 20, 204103.

41. Cukrowski, I., Matta, C.F. Hydrogen-hydrogen bonding: A stabilizing interaction in strained chelating rings of metal complexes in aqueous phase. Chem. Phys. Lett., 2010, 499, 66-69.

42. Matta, C.F. Modeling biophysical and biological properties from the characteristics of the molecular electron density, electron localization and delocalization matrices, and the electrostatic potential. J. Comput. Chem., 2014, 35, 1165-1198.

43. Lecomte, C., Espinosa, E., \& Matta, C.F. On atom-atom 'short contact' bonding interactions in crystals. IUCrJ, 2015, 2, 161-163.

44. Keith, T.A. (2010). AIMAll (Version 10.07.01). Retrieved from aim.tkgristmill.com.

45. Szabat, M., Kierzek, R. Parallel-stranded DNA and RNA duplexes: structural features and potential applications. FEBS J., 2017, 284, 3986-3998. 
Table 1. Vibrational and energetic characteristics of the tautomerically-conformational transformations of the G.C nucleobase pairs via the single (SPT) or double proton (DPT) transfer accompanied with the cis $\leftrightarrow$ trans conformational transformations through the quasi-orthogonal TSs as tight $\mathrm{G}^{+} \cdot \mathrm{C}^{-} / \mathrm{G}^{-} \cdot \mathrm{C}^{+}$ion pairs obtained at the MP2/6-311++G(2df,pd) // B3LYP/6-311++G(d,p) level of QM theory in the isolated state $(\varepsilon=1)$ under normal conditions (T=298.15 K) (see Fig. 1).

\begin{tabular}{|c|c|c|c|c|c|}
\hline $\begin{array}{c}\text { Tautomerically-conformational } \\
\text { transformations }\end{array}$ & $v_{i}^{\text {TSa }}$ & $\Delta \Delta \mathbf{G}_{\mathbf{T S}} \mathbf{b}^{\mathbf{b}}$ & $\Delta \Delta \mathbf{E}_{\mathbf{T S}}{ }^{\mathbf{c}}$ & $\Delta \mathbf{G}^{\mathbf{d}}$ & $\Delta \mathbf{E}^{\mathrm{e}}$ \\
\hline 1. $G \cdot C(W C) \leftrightarrow G \cdot C *\left(r_{W C}\right)$ & 28.9 & 29.86 & 29.77 & 11.68 & 12.12 \\
\hline 2. $G^{*} \cdot \mathbf{C} *(W C) \leftrightarrow G \cdot C^{*}\left(\mathrm{rw}_{\mathrm{WC}}\right)$ & 118.5 & 25.67 & 28.73 & 3.31 & 4.25 \\
\hline 3. $G^{*} \cdot C^{*}(W C) \leftrightarrow G^{*}{ }_{\mathrm{N} 2} \cdot C *\left(r_{W C}\right)$ & 447.7 & 62.00 & 64.07 & 27.94 & 29.24 \\
\hline 4. $\mathrm{G}^{*} \cdot \mathrm{C} *(\mathrm{rWC}) \leftrightarrow \mathrm{G}^{*} \cdot \mathrm{C}\left(\mathrm{w}_{\mathrm{WC}}\right)$ & 34.7 & 43.13 & 43.60 & 4.04 & 5.74 \\
\hline 5. G.C ${ }^{*}{ }_{02}(r W C) \leftrightarrow G \cdot C *\left(w_{W C}\right)$ & 677.5 & 30.67 & 33.10 & -0.74 & 0.03 \\
\hline 6. $G^{* t} \cdot C^{*}(H) \leftrightarrow G^{* t} \cdot C\left(r w_{H}\right)$ & 187.4 & 27.70 & 28.77 & 2.29 & 3.04 \\
\hline 7. $G^{* t} \cdot C^{*}(H) \leftrightarrow G^{* t} \cdot C * 02\left(w_{H}\right)$ & 195.4 & 29.03 & 30.13 & 16.63 & 17.20 \\
\hline 8. $G^{* t} \cdot C^{*}(H) \leftrightarrow G^{* t} \cdot C^{*}{ }_{02}\left(r w_{H}\right)$ & 1574.2 & 59.69 & 64.75 & 20.57 & 21.88 \\
\hline 9. $\mathbf{G}^{* \mathrm{t}} \cdot \mathrm{C}^{*}(\mathrm{H}) \leftrightarrow \mathrm{G}^{* \mathrm{t}} \mathrm{N}^{\circ} \mathbf{C}^{*}\left(\mathrm{rw}_{\mathrm{H}}\right)$ & 478.3 & 70.71 & 73.95 & 37.52 & 38.54 \\
\hline 9. $G^{* t}{ }_{N 7} \cdot C *\left(r W_{H}\right) \leftrightarrow G^{* t} \cdot C^{*}{ }_{O 2}\left(r w_{H}\right)$ & 1135.3 & 0.56 & 3.20 & -16.96 & -16.66 \\
\hline 10. $G^{*}{ }_{\mathrm{N} 7} \cdot \mathrm{C}(\mathrm{H}) \leftrightarrow \mathrm{G}^{* \mathrm{t}} \cdot \mathrm{C}\left(\mathrm{w}_{\mathrm{H}}\right)_{\text {amino }}$ & 417.0 & 19.14 & 21.81 & 3.56 & 4.72 \\
\hline 11. $G^{* t} \cdot C *(r H) \leftrightarrow G *{ }_{N 7} \cdot C *\left(w_{H}\right)$ & 304.0 & 38.88 & 39.16 & 14.35 & 15.11 \\
\hline 12. $G^{* t} \cdot C^{*}(\mathbf{r H}) \leftrightarrow G^{* t} \cdot C\left(w_{H}\right)$ & 303.8 & 46.77 & 49.74 & 2.43 & 4.56 \\
\hline 13. $G^{*{ }_{N} \cdot} \cdot C(r H) \leftrightarrow G^{* t}{ }_{N 7} \cdot C *\left(w_{H}\right)$ & 57.3 & 29.98 & 30.83 & 8.98 & 10.17 \\
\hline 13. $\mathrm{G}^{* \mathrm{t}} \mathrm{N}^{\cdot} \mathrm{C}^{*}\left(\mathrm{w}_{\mathrm{H}}\right) \leftrightarrow \mathrm{G}^{* \mathrm{t}} \cdot \mathrm{C}\left(\mathrm{w}_{\mathrm{H}}\right)$ & 1141.3 & -0.23 & 2.42 & -30.25 & -28.98 \\
\hline 14. $G^{*}{ }_{N} \cdot C^{*}\left(r w_{H}\right) \leftrightarrow G^{*}{ }_{N} \cdot C^{*}\left(r w_{H}\right)_{\text {perp }}$ & 32.8 & 8.25 & 7.09 & 5.95 & 5.52 \\
\hline 14. $\mathrm{G}^{*}{ }_{\mathrm{N} 7} \cdot \mathrm{C}^{*}\left(\mathrm{rw}_{\mathrm{H}}\right)_{\text {perp }} \leftrightarrow \mathrm{G}^{-} \cdot \mathrm{C}^{+}\left(\mathrm{rw}_{\mathrm{H}}\right)$ & 898.7 & 1.29 & 3.03 & 0.60 & -0.31 \\
\hline 14. $G^{-} \cdot C^{+}\left(r w_{H}\right) \leftrightarrow G^{* t} \cdot C\left(r w_{H}\right)$ & 39.1 & 3.39 & 3.11 & 5.13 & 0.16 \\
\hline
\end{tabular}

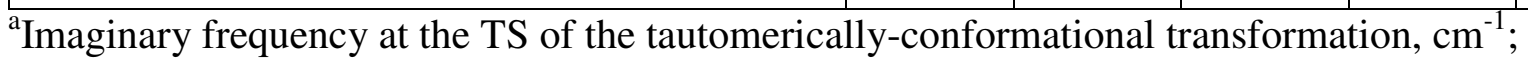

${ }^{b}$ Relative Gibbs free energy of the TS of the tautomerically-conformational transformation $(\mathrm{T}=298.15 \mathrm{~K}), \mathrm{kcal} \cdot \mathrm{mol}^{-1}$;

${ }^{c}$ Relative electronic energy of the TSs of the tautomerically-conformational transformation, $\mathrm{kcal} \cdot \mathrm{mol}^{-1}$;

${ }^{\mathrm{d}}$ Relative Gibbs free energy of the formed nucleobase pair $(\mathrm{T}=298.15 \mathrm{~K}), \mathrm{kcal} \cdot \mathrm{mol}^{-1}$;

${ }^{\mathrm{e}}$ Relative electronic energy of the formed nucleobase pair, $\mathrm{kcal} \cdot \mathrm{mol}^{-1}$. 


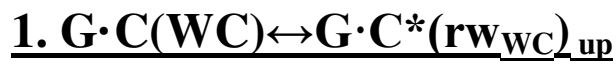
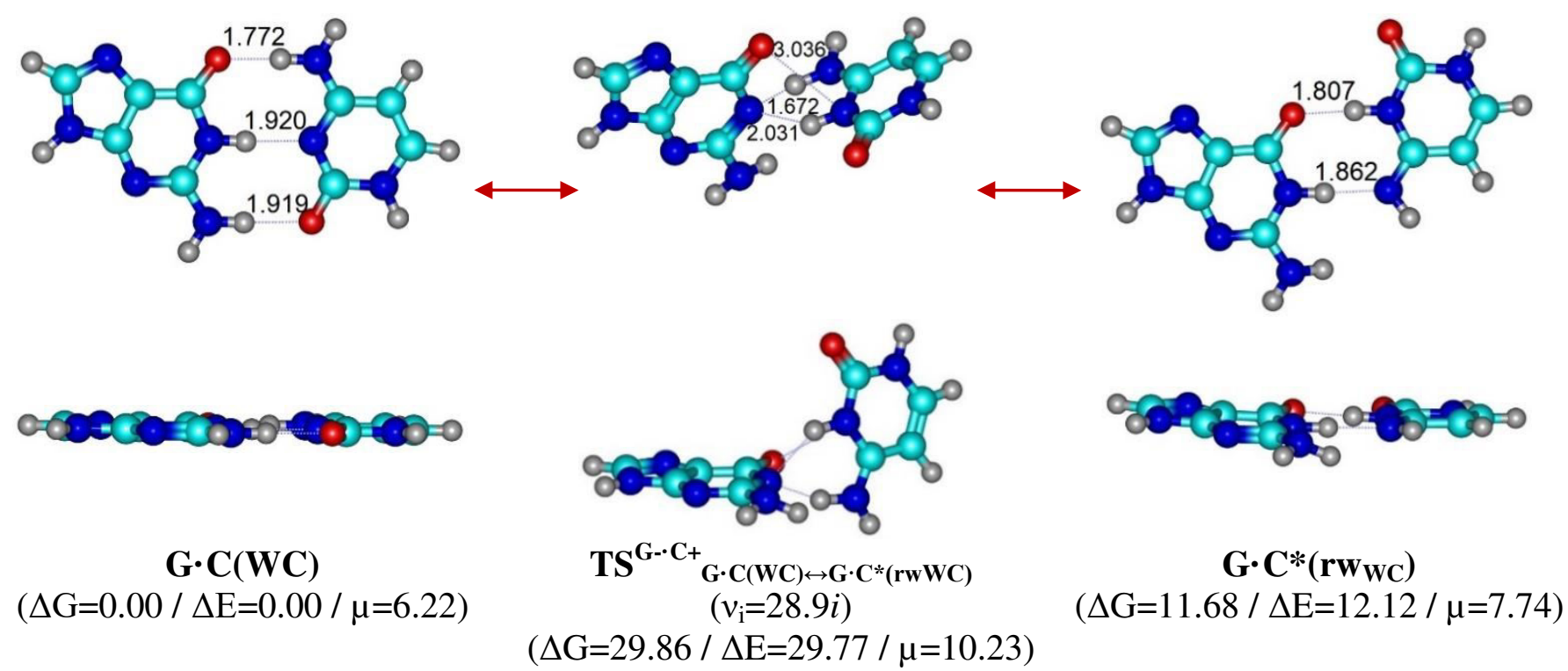

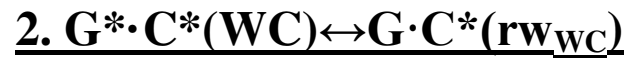

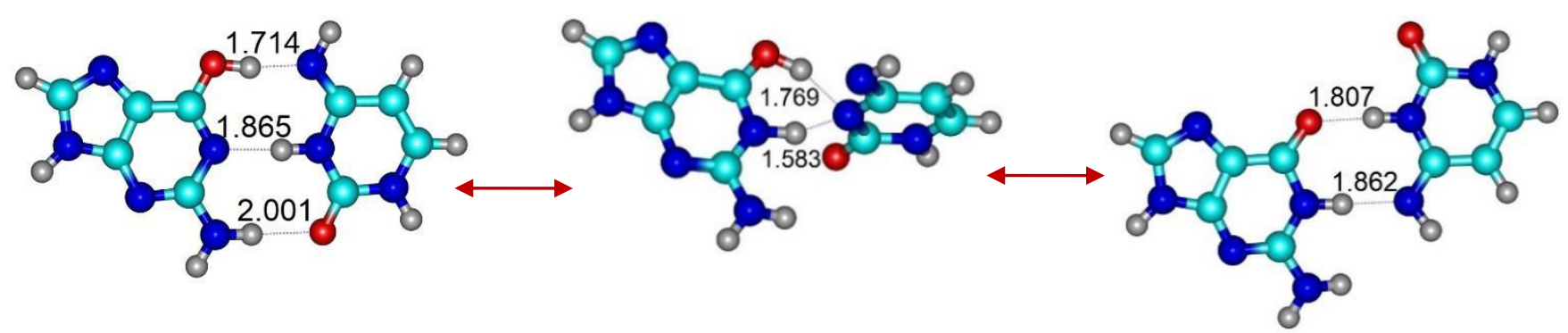

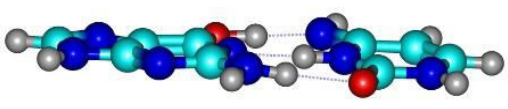

$\mathbf{G}^{*} \cdot \mathbf{C} *(\mathbf{W C})$

$(\Delta \mathrm{G}=0.00 / \Delta \mathrm{E}=0.00 / \mu=6.09)$

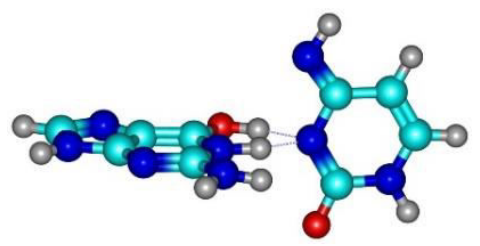

$\mathrm{TS}^{\mathrm{G}+\cdot \mathrm{C}-{ }_{\mathrm{C}}}$

$\left(v_{\mathrm{i}}=118.5 i\right)$

$(\Delta \mathrm{G}=25.67 / \Delta \mathrm{E}=28.73 / \mu=5.00)$

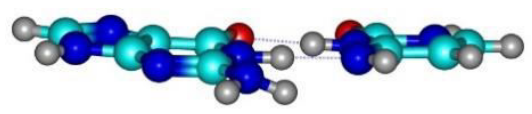

$\mathbf{G} \cdot \mathbf{C} *\left(\mathbf{r w}_{\mathbf{W C}}\right)$

$(\Delta \mathrm{G}=3.31 / \Delta \mathrm{E}=4.25 / \mu=7.74)$

\section{$\underline{\text { 3. } \mathrm{G}^{*} \cdot \mathrm{C}^{*}(\mathrm{WC}) \leftrightarrow \mathrm{G}^{*}} \underline{\mathrm{N} 2} \cdot \mathrm{C}^{*}\left(\mathrm{rw}_{\mathrm{wC}}\right)$}

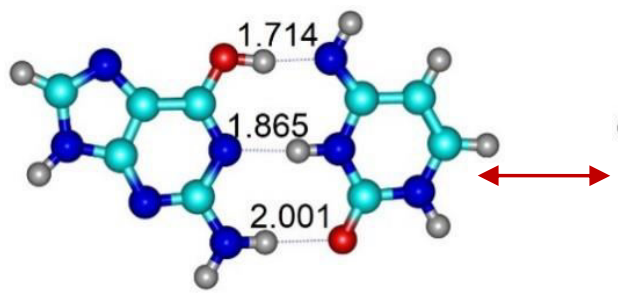

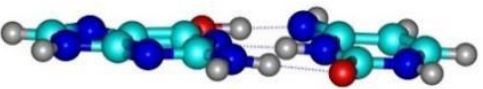

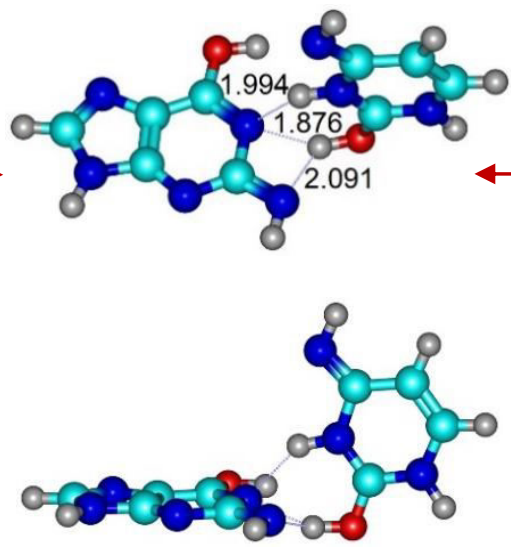

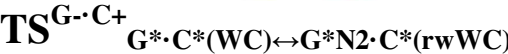

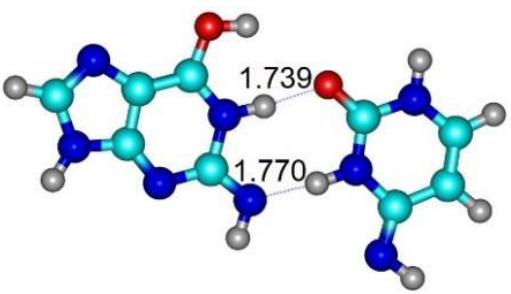

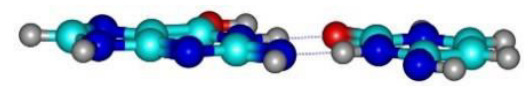




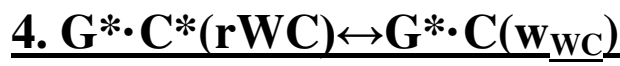
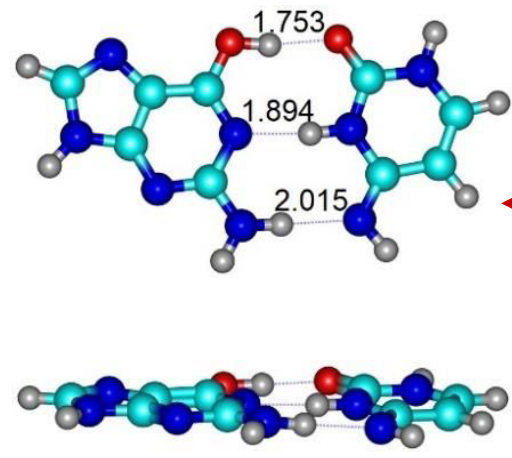

$\mathbf{G} * \mathbf{C} *(\mathbf{r W C})$

$(\Delta \mathrm{G}=0.00 / \Delta \mathrm{E}=0.00 / \mu=6.54)$
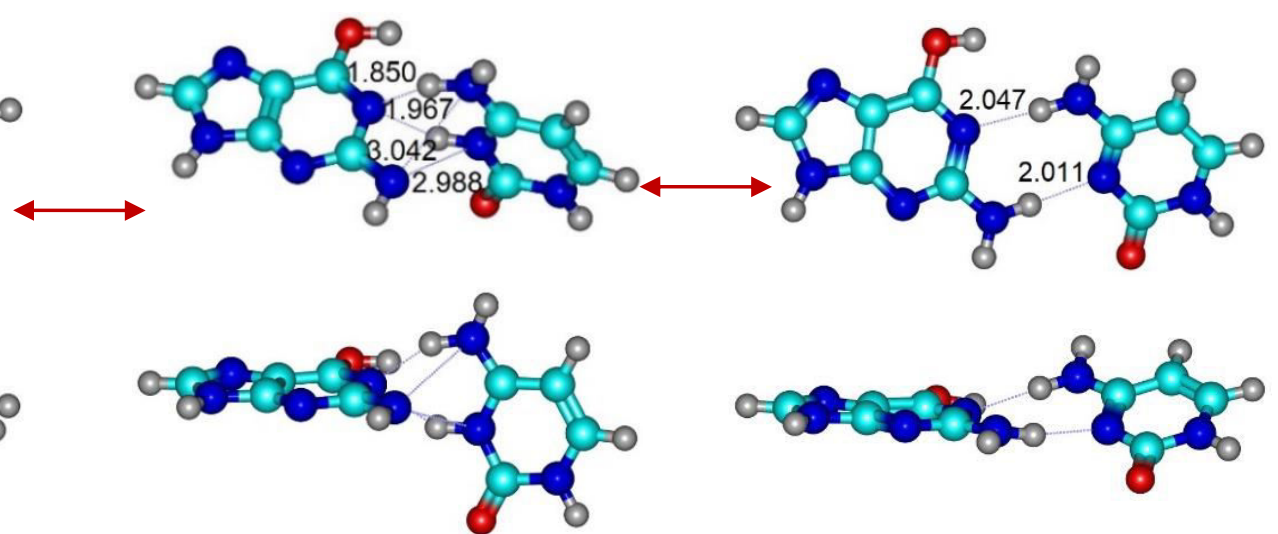

$\mathbf{T S}^{\mathrm{G} \cdot \cdot \mathrm{C}+} \mathrm{G}^{* *} \cdot \mathrm{C}^{*}(\mathbf{r W C}) \leftrightarrow \mathrm{G}^{* *} \cdot \mathrm{C}(\mathrm{wWC})$ $\left(v_{\mathrm{i}}=34.7 i\right)$

$(\Delta \mathrm{G}=43.13 / \Delta \mathrm{E}=43.60 / \mu=11.86)$

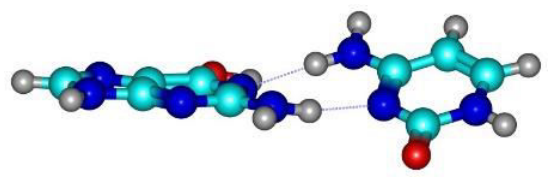

$\mathbf{G}^{*} \cdot \mathbf{C}\left(\mathbf{w}_{\mathrm{wC}}\right)$

$(\Delta \mathrm{G}=4.04 / \Delta \mathrm{E}=5.74 / \mu=4.70)$

\section{$\underline{5 . G \cdot C^{*}} \underline{02}(\mathbf{r W C}) \leftrightarrow \mathrm{G} \cdot \mathrm{C} *(\mathbf{w} \underline{\mathrm{wC}})$}
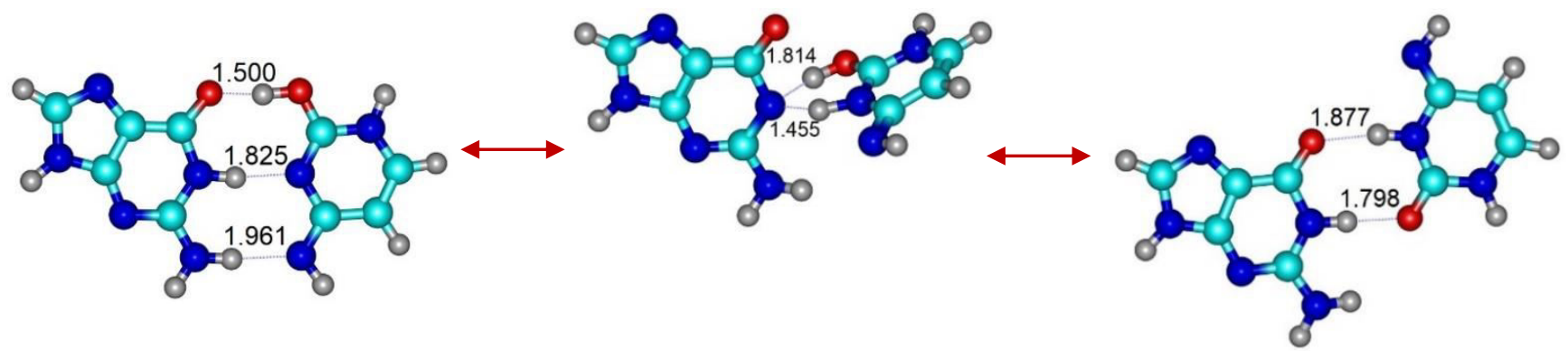

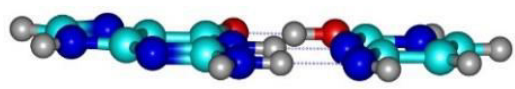

$\mathbf{G} \cdot \mathbf{C}^{*}{ }_{22}(\mathbf{r W C})$

$(\Delta \mathrm{G}=0.00 / \Delta \mathrm{E}=0.00 / \mu=5.43)$

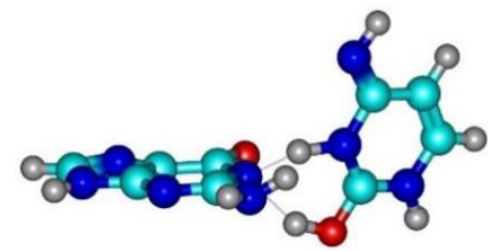

$\mathbf{T S}^{\mathrm{G} \cdot \cdot \mathrm{C}+}{ }_{\mathbf{G}} \cdot \mathbf{C} * \mathbf{O} 2(\mathbf{r W C}) \leftrightarrow \mathbf{G} \cdot \mathbf{C}^{*}(\mathbf{w W C})$ $\left(v_{\mathrm{i}}=677.5 i\right)$

$(\Delta \mathrm{G}=30.67 / \Delta \mathrm{E}=33.10 / \mu=8.14)$

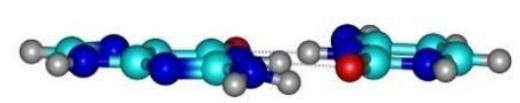

$\mathbf{G} \cdot \mathbf{C} *\left(\mathbf{w}_{\mathbf{W C}}\right)$

$(\Delta \mathrm{G}=-0.74 / \Delta \mathrm{E}=0.03 / \mu=7.29)$

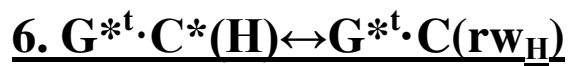
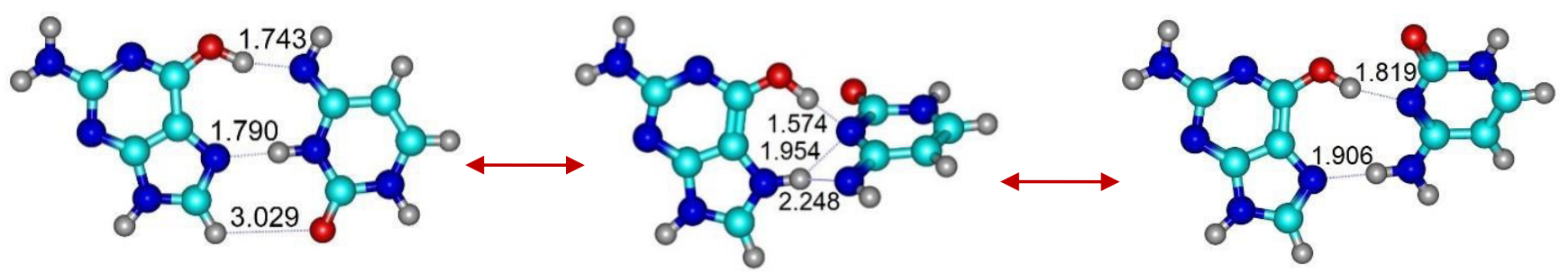

$0-0.608$ as

$\mathbf{G}^{* \mathrm{t}} \cdot \mathbf{C} *(\mathbf{H})$

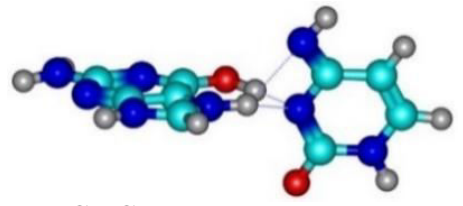

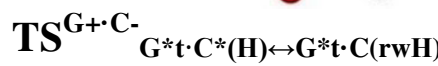

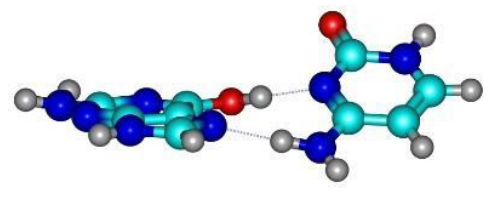

$\mathbf{G}^{* \mathrm{t} \cdot} \cdot \mathbf{C}\left(\mathbf{r w}_{\mathbf{H}}\right)$ 


\section{$\underline{7 . G^{* t} \cdot C^{*}(H) \leftrightarrow G^{* t} \cdot C^{*}} \underline{02}\left(\mathbf{W}_{\underline{H}}\right)$}
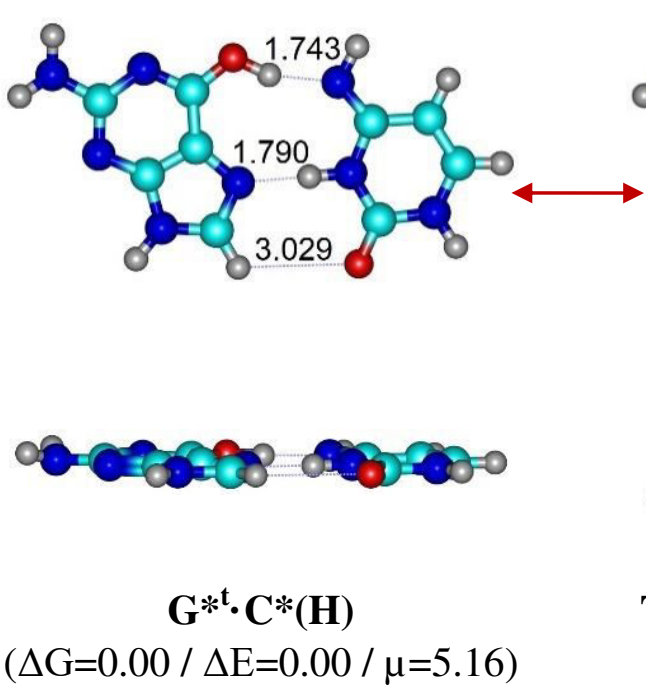
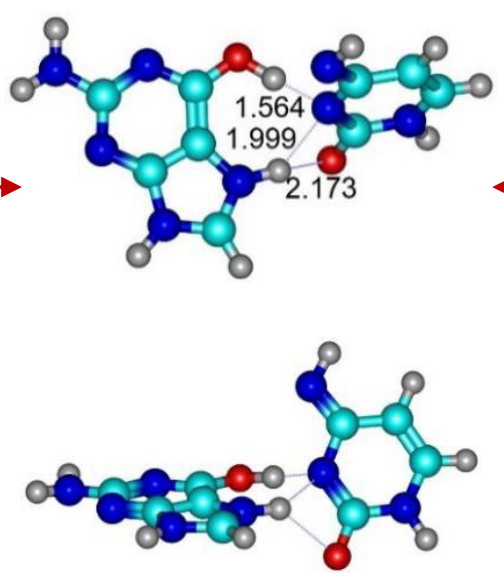

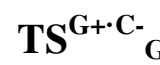

$\left(v_{\mathrm{i}}=195.4 i\right)$

$(\Delta \mathrm{G}=29.03 / \Delta \mathrm{E}=30.13 / \mu=6.83)$

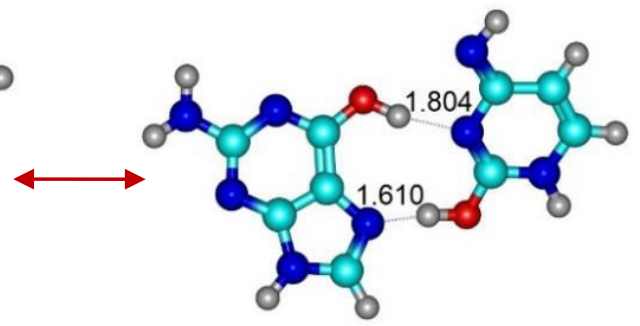

\section{$\underline{\text { 8. }} \mathrm{G}^{* \mathrm{t}} \cdot \mathrm{C} *(\mathrm{H}) \leftrightarrow \mathrm{G}^{* \mathrm{t}} \cdot \mathrm{C}^{*} \underline{\mathrm{O} 2} \underline{\left(\mathrm{rW}_{\mathrm{H}}\right)}$}
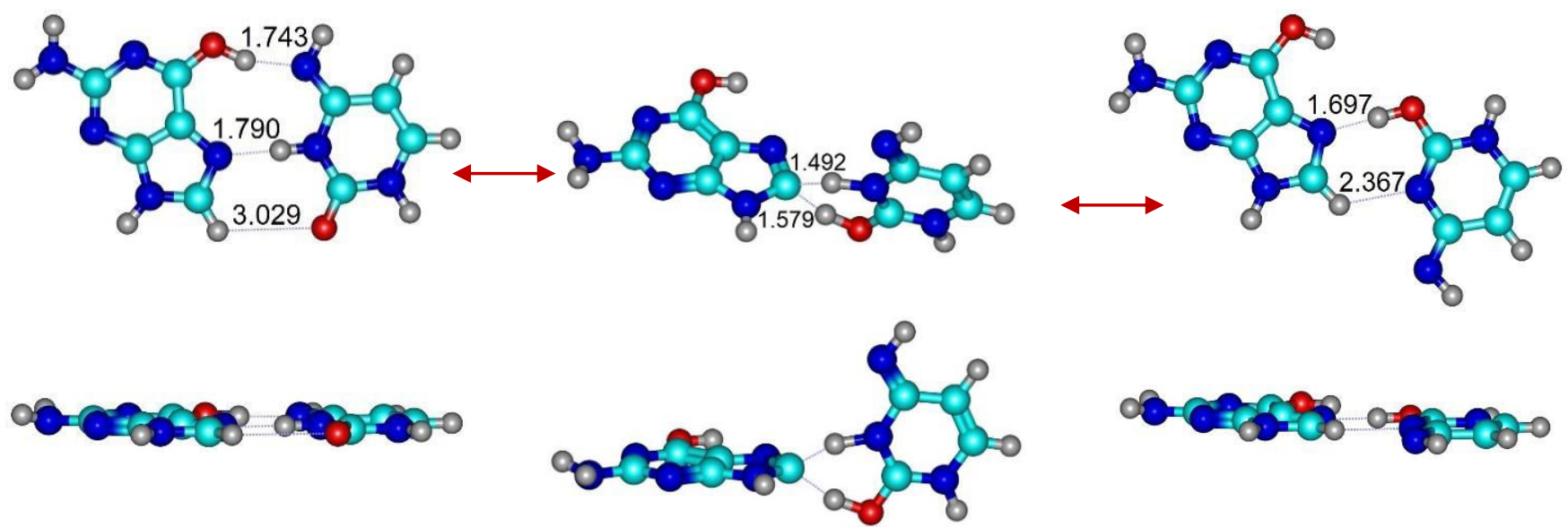

$$
\mathbf{G}^{*} \cdot \mathbf{C} *(\mathbf{H})
$$

$(\Delta \mathrm{G}=0.00 / \Delta \mathrm{E}=0.00 / \mu=5.16)$

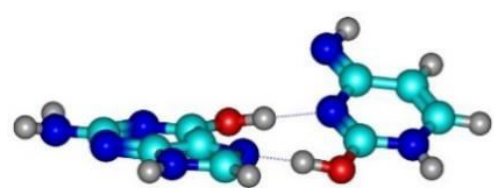

$\mathbf{G}^{* \mathrm{t}} \cdot \mathbf{C} * \mathrm{O}_{\mathbf{2}}\left(\mathbf{w}_{\mathbf{H}}\right)$ $(\Delta \mathrm{G}=16.63 / \Delta \mathrm{E}=17.20 / \mu=6.70)$

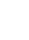

$$
\mathbf{T S}^{\mathbf{G} \cdot \cdot \mathbf{C}+} \mathbf{G}^{*} \mathbf{t} \cdot \mathbf{C} *(\mathbf{H}) \leftrightarrow \mathbf{G}^{*} \mathbf{t} \cdot \mathbf{C} * \mathbf{O} 2(\mathbf{r w H})
$$

$$
\left(v_{\mathrm{i}}=1574.2 i\right)
$$

$(\Delta \mathrm{G}=59.69 / \Delta \mathrm{E}=64.75 / \mu=9.89)$ 


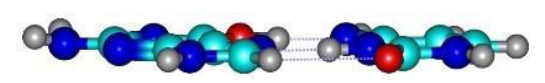

$$
\mathbf{G} * \mathbf{t} \cdot \mathbf{C} *(\mathbf{H})
$$

$(\Delta \mathrm{G}=0.00 / \Delta \mathrm{E}=0.00 / \mu=5.16)$

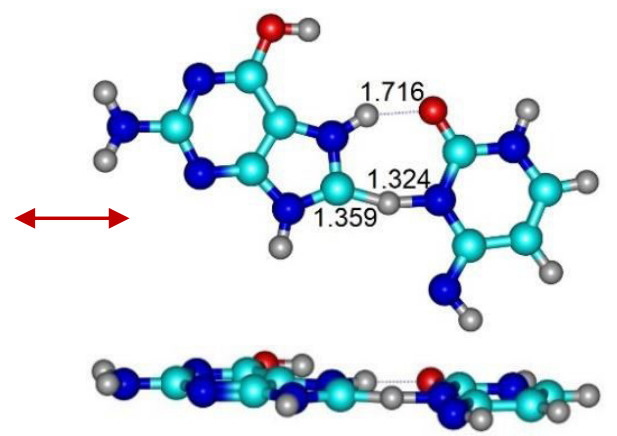

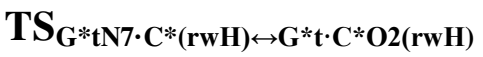
$\left(v_{\mathrm{i}}=1135.3 i\right)$

$(\Delta \mathrm{G}=38.08 / \Delta \mathrm{E}=41.74 / \mu=0.95)$

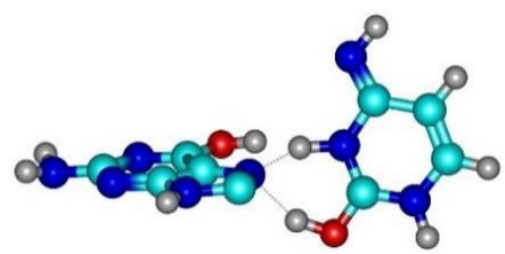

$\mathbf{T S}^{\mathbf{G} \cdot \cdot \mathbf{C}+}{ }_{\mathbf{G}}^{*} \cdot \mathbf{C}^{*}(\mathbf{H}) \leftrightarrow \mathbf{G}^{*} \mathrm{tN} \mathbf{7} \cdot \mathbf{C}^{*}(\mathbf{r w H})$ $\left(v_{\mathrm{i}}=478.3 i\right)$

$(\Delta \mathrm{G}=70.71 / \Delta \mathrm{E}=73.95 / \mu=9.95)$
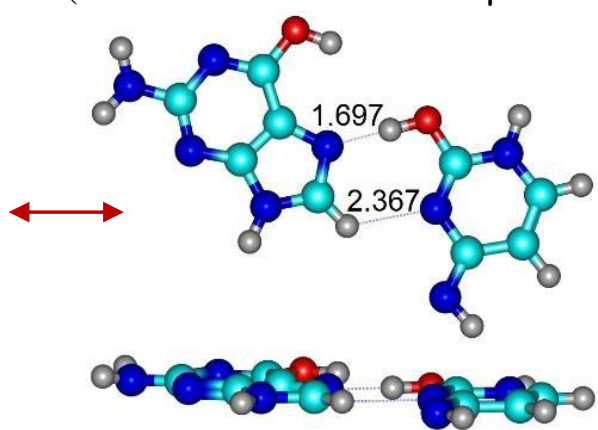

$$
\mathbf{G} * \mathbf{t} \cdot \mathbf{C} * \mathrm{O}_{2}\left(\mathbf{r w}_{\mathbf{H}}\right)
$$

$(\Delta \mathrm{G}=20.56 / \Delta \mathrm{E}=21.88 / \mu=2.36)$

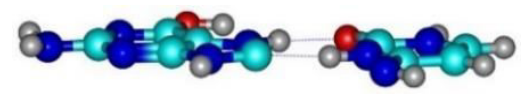

$\mathbf{G}^{*{ }^{\mathrm{t}} \mathbf{7}^{\cdot}} \mathbf{C} *\left(\mathbf{r w}_{\mathbf{H}}\right)$

$(\Delta \mathrm{G}=37.52 / \Delta \mathrm{E}=38.54 / \mu=4.41)$

\section{$\underline{10 .} \mathrm{G}^{*}{ }^{\mathrm{N} 7} \cdot \mathrm{C}(\mathrm{H}) \leftrightarrow \mathrm{G}^{* \mathrm{t}} \cdot \mathrm{C}\left(\mathrm{w}_{\mathrm{H}} \underline{\mathrm{amino}}_{\underline{\text { aming }}}\right.$}

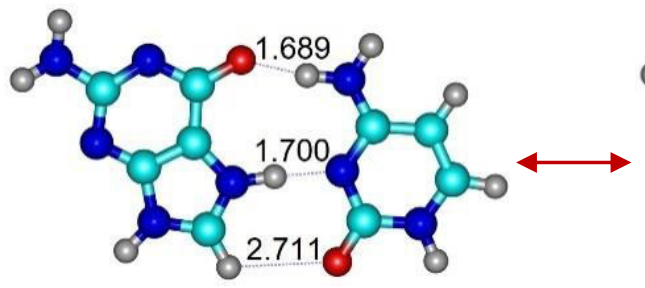

$0.0520-000$

$\mathbf{G}^{*}{ }_{\mathrm{N} 7} \cdot \mathbf{C}(\mathbf{H})$

$(\Delta \mathrm{G}=0.00 / \Delta \mathrm{E}=0.00 / \mu=7.32)$
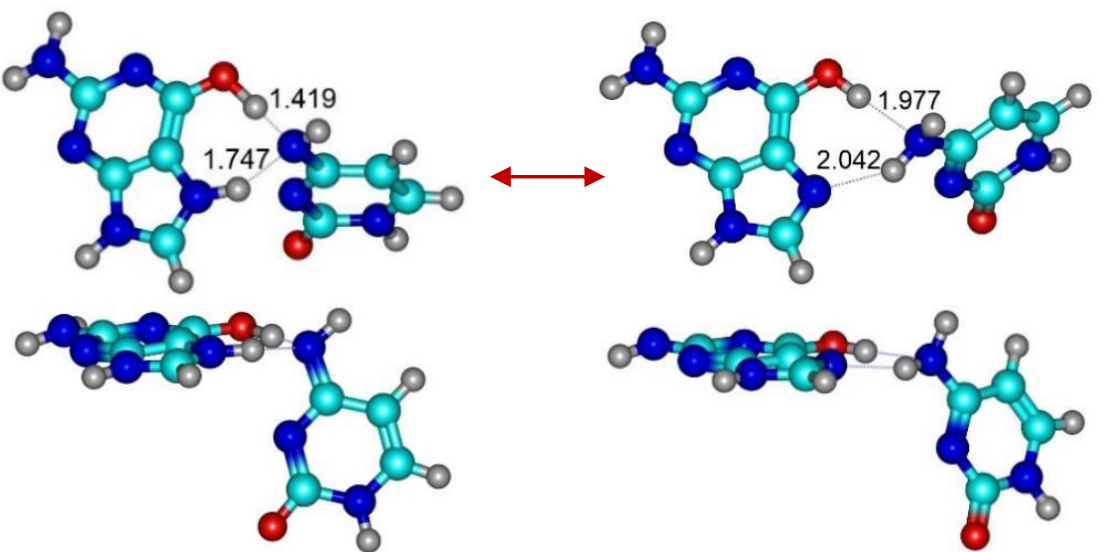

$\mathbf{T S}^{\mathbf{G + \cdot} \mathbf{C}-\mathbf{G}^{*} \mathbf{N} 7 \cdot \mathbf{C}(\mathbf{H}) \leftrightarrow \mathbf{G}^{*} \mathbf{t} \cdot \mathbf{C}(\mathbf{w H}) \text { amino }}$ $\left(v_{\mathrm{i}}=417.0 i\right)$

$\mathbf{G} * \mathbf{t} \cdot \mathbf{C}\left(\mathbf{w}_{\mathrm{H}}\right)$ amino

$(\Delta \mathrm{G}=3.56 / \Delta \mathrm{E}=4.72 / \mu=4.29)$ $(\Delta \mathrm{G}=19.14 / \Delta \mathrm{E}=21.81 / \mu=5.58)$

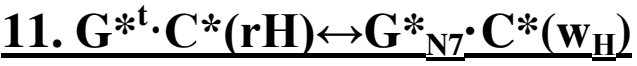
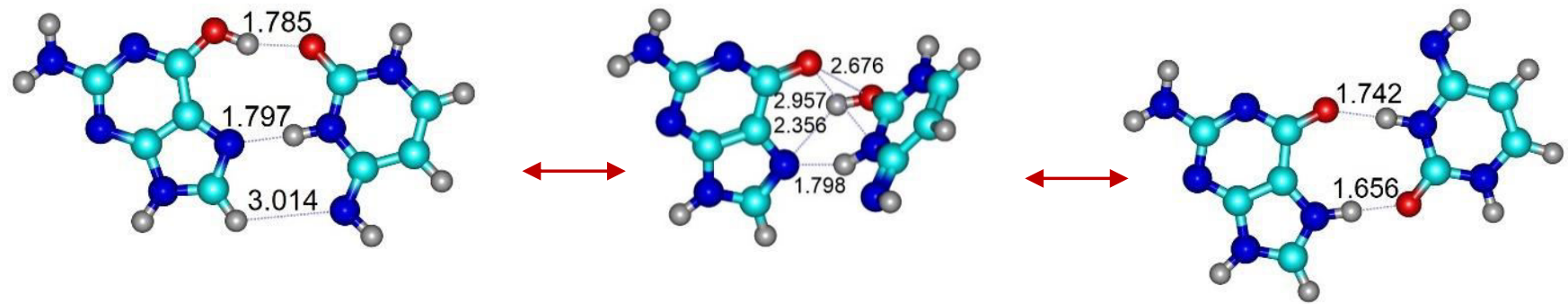


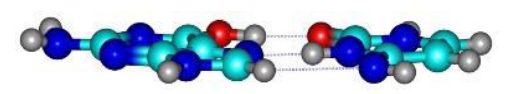

$\mathbf{G}^{* \mathbf{t}} \cdot \mathbf{C} *(\mathbf{r H})$

$(\Delta \mathrm{G}=0.00 / \Delta \mathrm{E}=0.00 / \mu=6.14)$

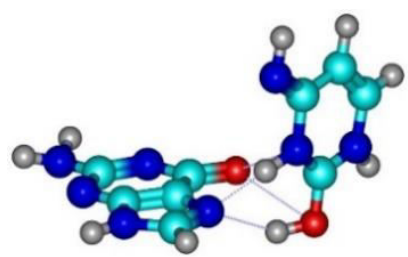

$\mathbf{T S}^{\mathbf{G} \cdot \cdot \mathbf{C}+} \mathbf{G}^{*} \mathbf{t} \cdot \mathbf{C} *(\mathbf{r H}) \leftrightarrow \mathbf{G}^{*} \mathbf{N} 7 \cdot \mathbf{C}^{*}(\mathbf{w H})$ $\left(v_{\mathrm{i}}=304.0 i\right)$

$(\Delta \mathrm{G}=38.88 / \Delta \mathrm{E}=39.16 / \mu=8.63)$

\section{0}

\author{
$\mathbf{G}^{*}{ }_{\mathrm{N} 7} \cdot \mathbf{C} *\left(\mathbf{w}_{\mathbf{H}}\right)$
}

$(\Delta \mathrm{G}=14.35 / \Delta \mathrm{E}=15.11 / \mu=9.46)$

\section{$\underline{12 .} \mathbf{G}^{* \mathrm{t}} \cdot \mathbf{C} *(\mathbf{r H}) \leftrightarrow \mathrm{G}^{* \mathrm{t}} \cdot \mathbf{C}\left(\mathbf{w}_{\underline{H}}\right)$}

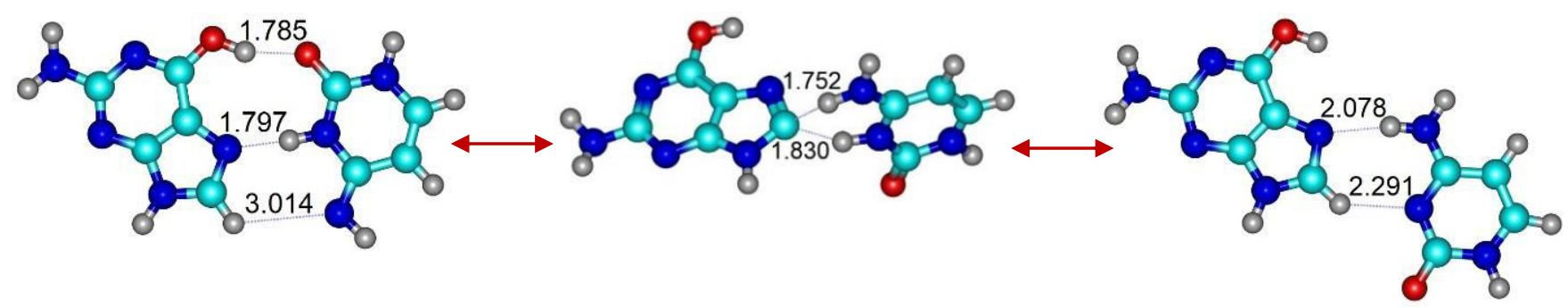

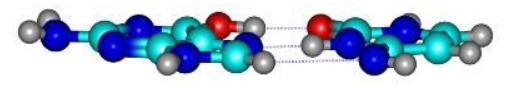

$\mathbf{G} * \mathbf{t} \cdot \mathbf{C} *(\mathbf{r H})$

$(\Delta \mathrm{G}=0.00 / \Delta \mathrm{E}=0.00 / \mu=6.14)$

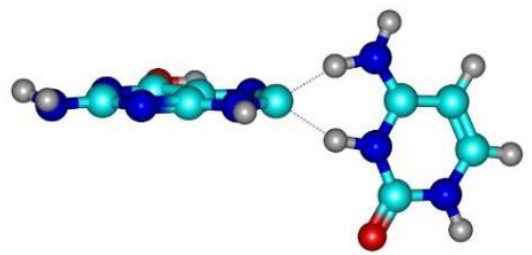

$\mathbf{T S}^{\mathbf{G} \cdot \cdot \mathbf{C}+}{ }_{\mathbf{G}^{*}} \cdot \mathbf{t} \cdot \mathbf{C} *(\mathbf{r H}) \leftrightarrow \mathbf{G}^{*} \mathbf{t} \cdot \mathbf{C}(\mathbf{w H})$ $\left(v_{\mathrm{i}}=303.8 i\right)$

$(\Delta \mathrm{G}=46.77 / \Delta \mathrm{E}=49.74 / \mu=13.64)$

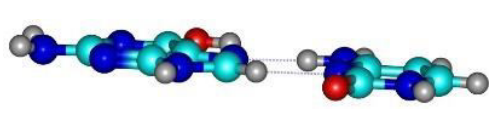

$\mathbf{G} * \mathbf{t} \cdot \mathbf{C}\left(\mathbf{w}_{\mathbf{H}}\right)$

$(\Delta \mathrm{G}=2.43 / \Delta \mathrm{E}=4.56 / \mu=4.66)$

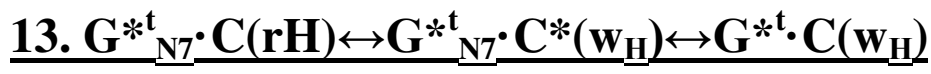

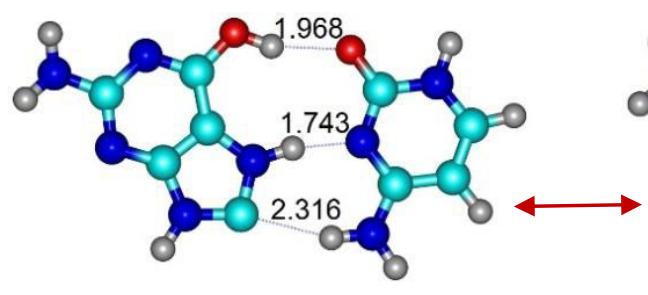

$28+80$

$$
\mathbf{G}^{*}{ }_{\mathrm{N} 7}^{\mathrm{t}} \cdot \mathbf{C}(\mathbf{r H})
$$

$(\Delta \mathrm{G}=0.00 / \Delta \mathrm{E}=0.00 / \mu=9.01)$
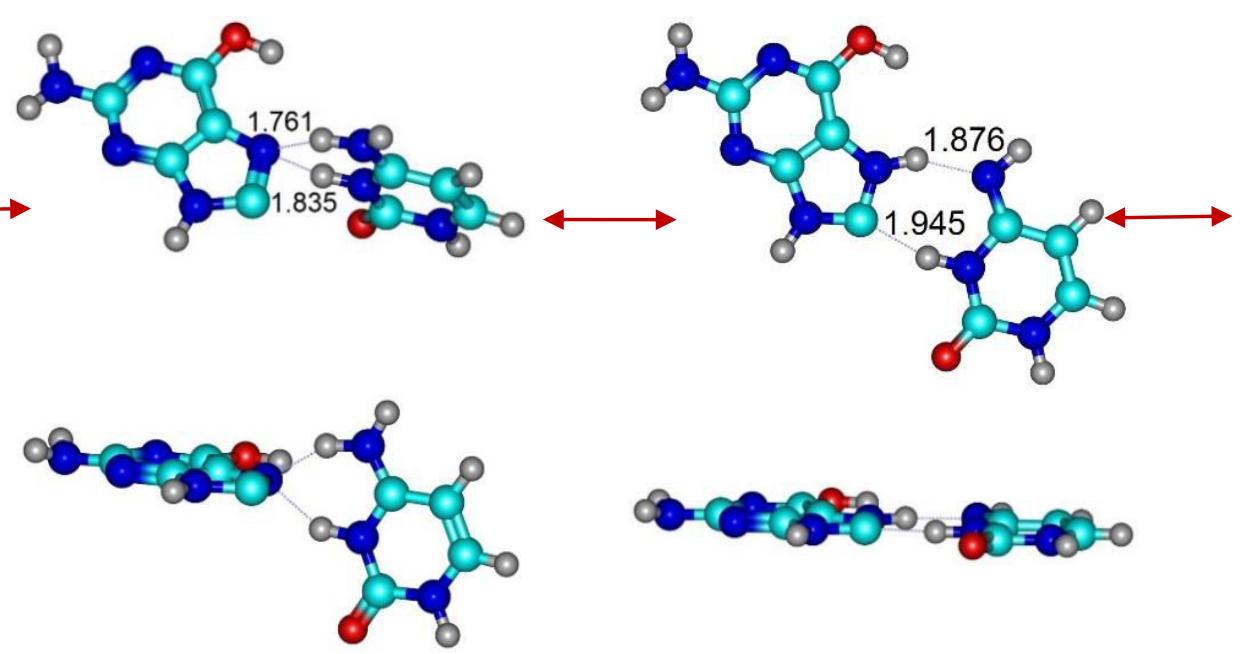

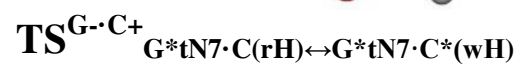
$\left(v_{\mathrm{i}}=57.3 i\right)$ $(\Delta \mathrm{G}=8.98 / \Delta \mathrm{E}=10.17 / \mu=4.81)$

$(\Delta \mathrm{G}=29.98 / \Delta \mathrm{E}=30.83 / \mu=12.81)$

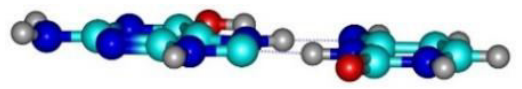

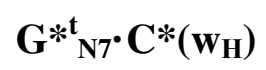




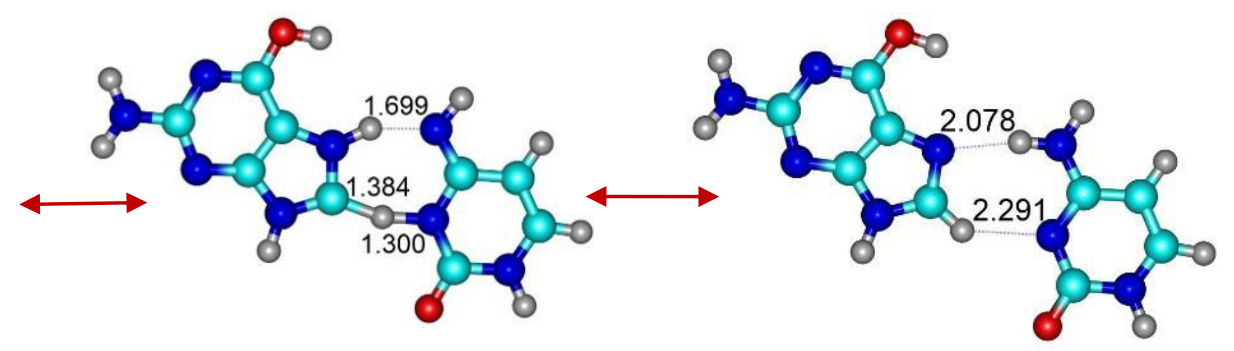

$6-c=000-8=0$

$\mathbf{T S}_{\mathbf{G}^{*} * \mathbf{N} 7 \cdot \mathbf{C}^{*}(\mathbf{w H}) \leftrightarrow \mathbf{G}^{* \mathbf{t}} \cdot \mathbf{C}(\mathbf{w H})}$

$\left(v_{\mathrm{i}}=1141.3 i\right)$

$0-\cos 60$ o 00

$\mathbf{G} * \mathbf{t} \cdot \mathbf{C}\left(\mathbf{w}_{\mathbf{H}}\right)$

$(\Delta \mathrm{G}=-21.27 / \Delta \mathrm{E}=-18.81 / \mu=4.66)$

$(\Delta \mathrm{G}=8.75 / \Delta \mathrm{E}=12.59 / \mu=9.89)$

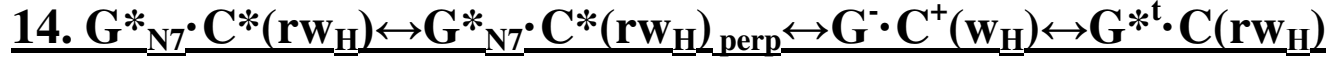
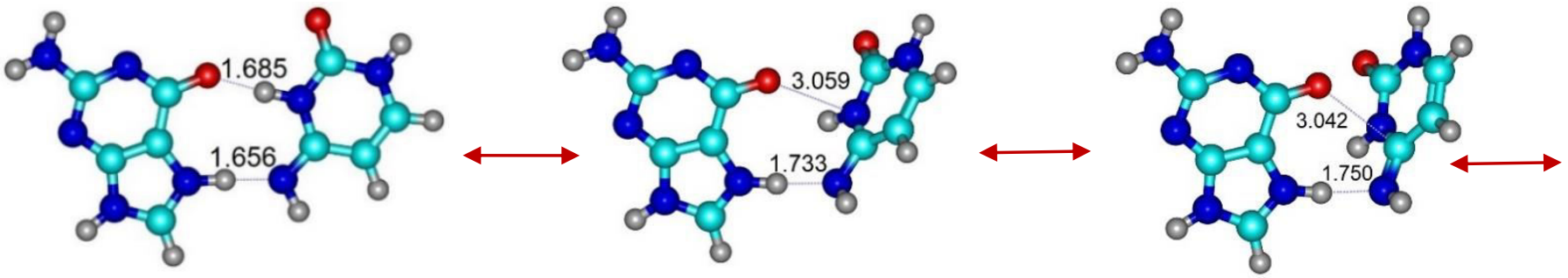

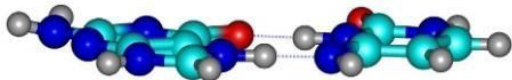

$\mathbf{G}^{*}{ }_{\mathrm{N} 7} \cdot \mathbf{C} *\left(\mathbf{r w}_{\mathbf{H}}\right)$

$(\Delta \mathrm{G}=0.00 / \Delta \mathrm{E}=0.00 / \mu=10.28)$
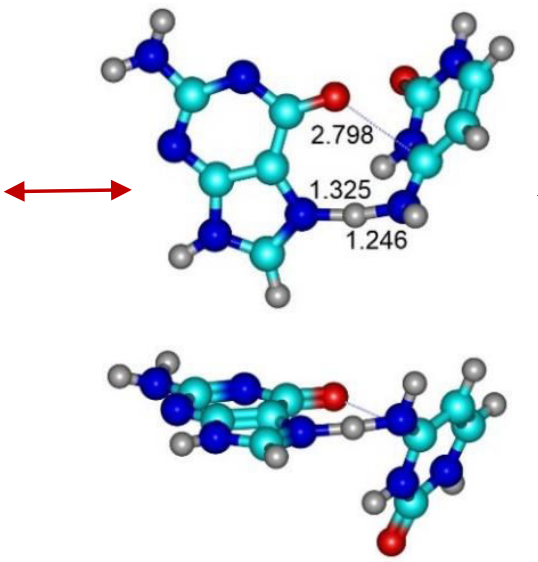

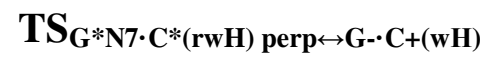
$\left(v_{\mathrm{i}}=898.7 i\right)$

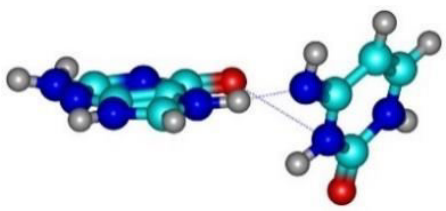

$\mathbf{T S}_{\mathbf{G} * \mathbf{N} 7 \cdot \mathbf{C} *(\mathbf{r w H}) \leftrightarrow \mathbf{G}^{*} \mathrm{~N} 7 \cdot \mathbf{C} *(\mathbf{r w H}) \text { perp }}$ $\left(v_{\mathrm{i}}=32.8 i\right)$ $(\Delta \mathrm{G}=8.25 / \Delta \mathrm{E}=7.09 / \mu=7.81)$
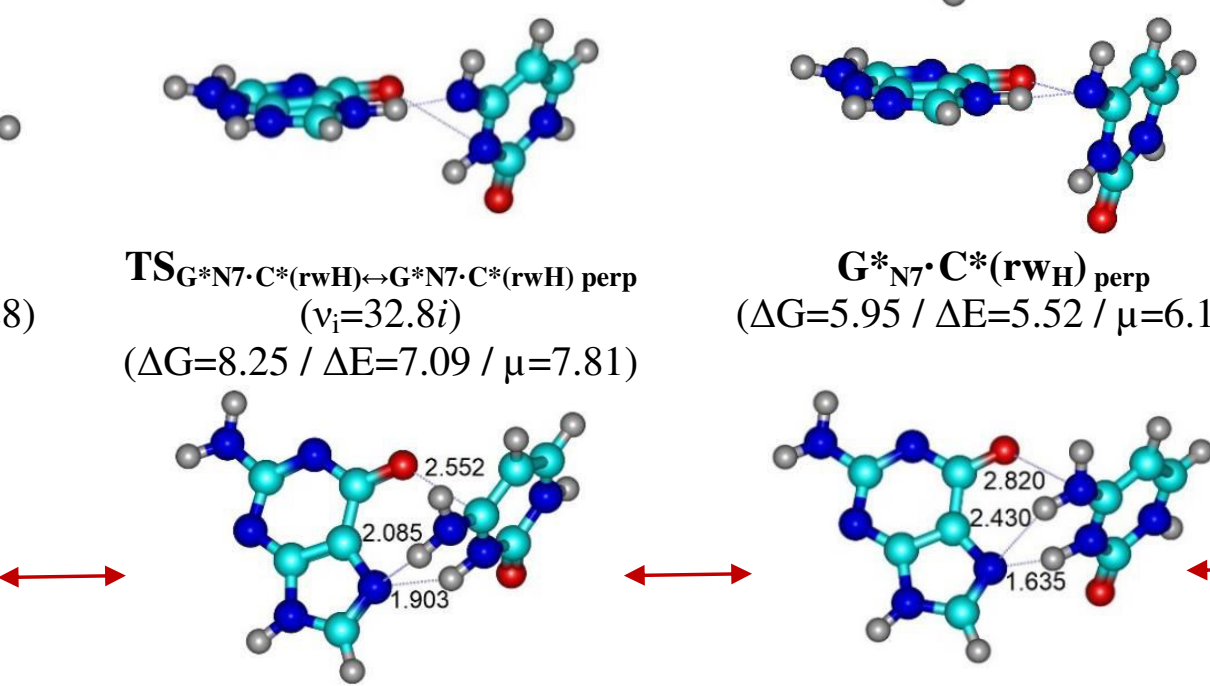

$\mathbf{G}^{*}{ }_{\mathrm{N}} \cdot \mathbf{C}^{*}\left(\mathbf{r w}_{\mathrm{H}}\right)_{\text {perp }}$ $(\Delta \mathrm{G}=5.95 / \Delta \mathrm{E}=5.52 / \mu=6.18)$
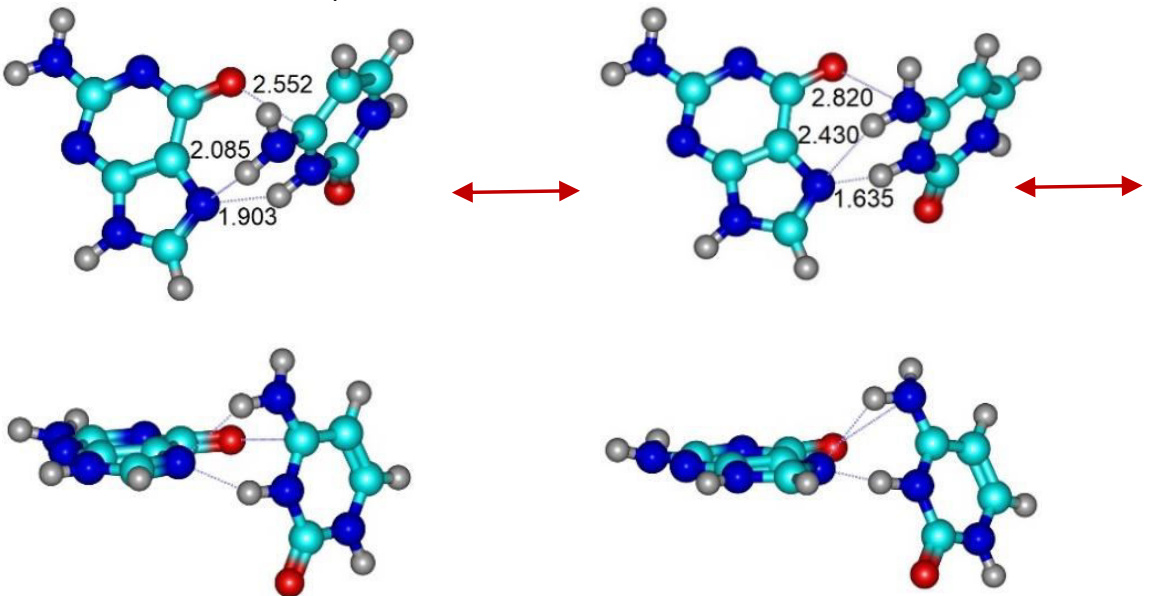

$\mathbf{G}^{-} \cdot \mathbf{C}^{+}\left(\mathbf{w}_{\mathbf{H}}\right)$

$(\Delta \mathrm{G}=6.55 / \Delta \mathrm{E}=5.21 / \mu=8.09)$

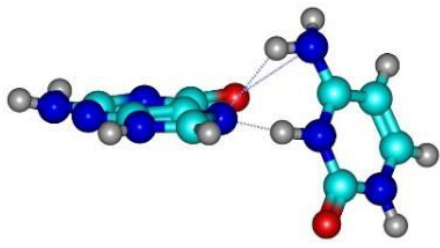

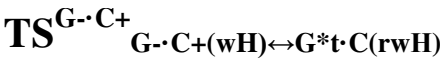
$\left(v_{\mathrm{i}}=39.1 i\right)$ $(\Delta \mathrm{G}=9.94 / \Delta \mathrm{E}=8.32 / \mu=11.08)$ $(\Delta \mathrm{G}=7.24 / \Delta \mathrm{E}=8.55 / \mu=7.53)$

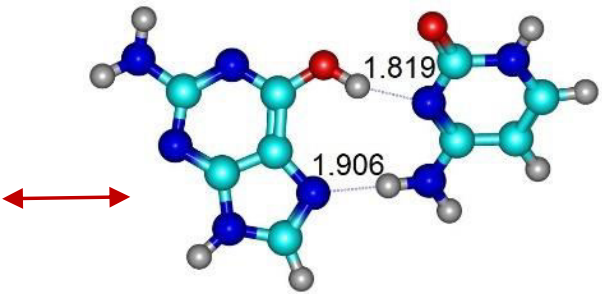




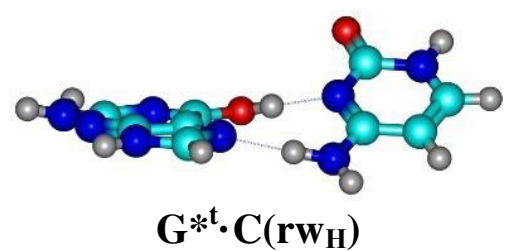

$(\Delta \mathrm{G}=-11.39 / \Delta \mathrm{E}=-11.68 / \mu=8.25)$

Fig. 1. Reaction pathways of the tautomerically-conformational transformations of the biologically important G.C nucleobase pairs via the quasi-orthogonal TSs as tight $\mathrm{G}^{+} \cdot \mathrm{C}^{-} / \mathrm{G}^{-} \cdot \mathrm{C}^{+}$ion pairs, obtained at the MP2/6-311++G(2df,pd)//B3LYP/6-311++G(d,p) level of QM theory in the isolated state ( $v_{i}$ - imaginary frequency in $\mathrm{cm}^{-1}, \Delta \mathrm{G}$ - relative Gibbs free energy in $\mathrm{kcal} \cdot \mathrm{mol}^{-1}, \Delta \mathrm{E}-$ electronic energy in $\mathrm{kcal} \cdot \mathrm{mol}^{-1}$ ). Intermolecular $\mathrm{AH} \cdots \mathrm{B} \mathrm{H}$-bonds and $\mathrm{A} . . \mathrm{B}$ attractive van der Waals contacts are designated by the dotted lines, their lengths $\mathrm{H} \cdots \mathrm{B}$ and $\mathrm{A} \cdots \mathrm{B}$ are presented in angstroms. 